\title{
The diffusion of computers and the distribution of wages
}

Citation for published version (APA):

Borghans, L., \& ter Weel, B. J. (2002). The diffusion of computers and the distribution of wages.

Researchcentrum voor Onderwijs en Arbeidsmarkt, Faculteit der Economische Wetenschappen. ROA Research Memoranda No. 5E https://doi.org/10.26481/umaror.200205E

Document status and date:

Published: 01/01/2002

DOI:

10.26481/umaror.200205E

Document Version:

Publisher's PDF, also known as Version of record

\section{Please check the document version of this publication:}

- A submitted manuscript is the version of the article upon submission and before peer-review. There can be important differences between the submitted version and the official published version of record.

People interested in the research are advised to contact the author for the final version of the publication, or visit the DOI to the publisher's website.

- The final author version and the galley proof are versions of the publication after peer review.

- The final published version features the final layout of the paper including the volume, issue and page numbers.

Link to publication

\footnotetext{
General rights rights.

- You may freely distribute the URL identifying the publication in the public portal. please follow below link for the End User Agreement:

www.umlib.nl/taverne-license

Take down policy

If you believe that this document breaches copyright please contact us at:

repository@maastrichtuniversity.nl

providing details and we will investigate your claim.
}

Copyright and moral rights for the publications made accessible in the public portal are retained by the authors and/or other copyright owners and it is a condition of accessing publications that users recognise and abide by the legal requirements associated with these

- Users may download and print one copy of any publication from the public portal for the purpose of private study or research.

- You may not further distribute the material or use it for any profit-making activity or commercial gain

If the publication is distributed under the terms of Article $25 \mathrm{fa}$ of the Dutch Copyright Act, indicated by the "Taverne" license above, 


\section{The Diffusion of Computers and the Distribution of Wages*}

ROA-RM-2002/5E

Lex Borghans, Bas ter Weel

* We thank David Autor, Eve Caroli, Frank Cörvers, Paul David, Machiel van Dijk, Arnaud Dupuy, Luis Caricano, Austan Goolsbee, Andries de Grip, Jonathan Guryan, Jim Heckman, Tom Hubbard, Boyan Jovanovic, Joseph Kaboski, Erzo Luttmer, Omer Moav, Kevin Murphy, Derek Neal, Lars Nesheim, Paul Stoneman, Bob Topel, John van Reenen, Gianluca Violante, Bruce Weinberg, and seminar participants at the Central Planning Bureau, the 2002 EALE in Paris, IZA, Maastricht University, Ohio State University, the Tinbergen Institute, the University of Chicago, the University of Groningen, and ZEW for helpful comments. We acknowledge the Netherlands Organization for Scientific Research (NWO) for financial support.

\section{Research Centre for Education and the Labour Market}

Faculty of Economics and Business Administration

Maastricht University

Maastricht, December 2002 
ISBN 90-5321-350-3

Sec02.213.doc 


\begin{abstract}
This paper models the impact of the diffusion of computers on the wage structure, starting from the observation that computer use increases individual productivity, but also the supply of goods. This latter effect negatively affects workers producing similar goods. If the productivity gain is proportional, and the costs of a computer are equal for everyone, workers with high wages are the first to adopt, leading to within-group wage inequality. Distinguishing skilled and unskilled workers we show that between-group wage inequality falls when the first skilled workers adopt computers. When unskilled workers start to use computers, between group wage inequality increases strongly because of the increased supply of unskilled labor in terms of efficiency units. The maximum level of wage inequality depends mainly on parameters regarding the distribution of the productivity of workers within and between groups: A large initial level of wage inequality leads to a large short term relative increase in wage inequality. In the long run, when all workers have adopted computers, both withingroup and between-group wage inequality fall to a level depending on differences in productivity gains from using computers. Empirically it is shown that the model is consistent with the pattern of wage inequality in the United States in the period 1963-2000. The current pattern is mainly determined by the short term determinants of wage inequality, making the long run implications difficult to identify and predict.
\end{abstract}

Keywords: Wage Inequality; Wage Level and Structure; Computerization

JEL Codes: J31, O30 



\section{Introduction}

It has been well documented that wage inequality in the United States has accelerated upon the emergence of computers in the labor market. ${ }^{1}$ Several studies have suggested that the increase in wage inequality since the early 1980 s has been caused by a complementary relationship between computers and skilled labor. Indeed, computer use is more concentrated among skilled workers and associated with higher earnings. ${ }^{2}$ However, already in the early 1970s a non-negligible part of the workforce had access to mainframe computers, which did not lead to wage inequality at that time (Bresnahan, 1999). In addition, wage inequality decreased until the early 1980s and although the diffusion of computers is still far from complete, the increase in wage inequality seems to be leveling off in the 1990s (Card and DiNardo, 2002).

In this paper we propose a model which is able to explain these observations. We do so by explicitly taking into account the diffusion process of computers, starting from the simple observation that computerization increases individual productivity but also the supply of goods. Computer use by a particular group of workers therefore negatively affects workers in the same group not using a computer but producing a similar good. The model contains three main features. First, the diffusion of computers is based on cost-benefit considerations

\footnotetext{
${ }^{1}$ Greenwood and Yorukoglu (1997) argue that the mid-1970s are the watershed in the acceleration of wage inequality because the price of computer equipment fell faster after 1974 than before, which fosters adoption. Katz (2000) argues that wage inequality began to rise in the early 1980s, just after the invention of microcomputers. See also Katz and Murphy (1992), Bound and Johnson (1992), Juhn, Murphy and Pierce (1993), Autor, Katz and Krueger (1998), Krusell, Ohanian, Ríos-Rull and Violante (2000); and Johnson (1997), Katz and Autor (1999), Acemoglu (2002), Aghion (2002), and Card and DiNardo (2002) for overviews and criticism.

${ }^{2}$ See for example Krueger (1993) for the seminal paper suggesting that computer users earn higher wages because of skill advantages, explaining about one half of the widening of the educational wage structure in the period 1984-1989. Levy and Murnane (1996) and Autor, Levy and Murnane (2002) argue that the introduction of computers in a large U.S. bank has induced substitution of unskilled for skilled workers. Berman, Bound and Griliches (1994), Doms, Dunne and Troske (1997), Autor, Katz and Krueger (1998), Allen (2001), and Bresnahan, Brynjolfsson and Hitt (2002) observe that higher levels of computerization and investments in computer equipment are associated with higher levels of skill and education in the workforce.
} 
weighing the productivity benefits against the costs of computer use, which induces adoption among high-wage workers first. Secondly, by distinguishing two groups of workers (skilled and unskilled), each producing one similar good, but with productivity differences between workers, we derive analytical results for wage developments both within and between different groups of workers. Thirdly, we explicitly model the assignment of computers to workers. Due to productivity differences not all workers adopt at the same time and limited substitution between skilled and unskilled workers leads to different effects on wages within and between groups.

The main results of the paper are the following. The pattern and structure of wages over time predicted by the model show different effects for between-group and within-group wage inequality. Between-group wage inequality is falling when the first skilled workers adopt computers because the additional supply in efficiency units depresses average skilled wages more than the productivity gains increase wages. When more skilled workers adopt computers, and when unskilled workers start to use computers, between-group wage inequality will increase strongly because the productivity gains skilled workers experience outweigh the additional supply of skilled labor in efficiency units. More importantly, the supply of additional efficiency units of unskilled workers increases between-group wage inequality. When all workers have adopted computers, wage inequality falls to a level depending on differences in productivity gains between skilled and unskilled workers. When skilled (unskilled) workers benefit more, between-group wage inequality will be permanently higher (lower). However, the short term effects on between-group wage inequality are much higher than the long term effects. We also show that the maximum level of between-group wage inequality is higher the higher the level initial wage inequality.

Within-group wage inequality for skilled (unskilled) workers is increasing once the 
first skilled (unskilled) workers have adopted computers. This is the case because all workers in a group suffer in terms of wages from the additional supply of efficiency units, but only the adopters benefit from the productivity gain from using a computer. If all workers within a group have adopted computers, within-group wage inequality in that group falls to the level prior to computer adoption if the productivity gains for every worker within the same group are the same.

Empirically, we show that the pattern of wage inequality predicted by the model is consistent with the pattern and timing of wage inequality in the United States in the period 1963-2000. Using CPS data, we find the productivity gains from using computers to be between 15 and 40 percent, both for skilled and unskilled workers. This is consistent with estimates of the costs of computers relative to annual wages. Because currently not all workers have adopted computers, the short term effects of computer adoption are dominating the structural long term productivity effects. Based on past and current developments in the wage structure, it is therefore hard to precisely point out whether skilled or unskilled workers benefit most in terms of productivity gains. As a result, the current developments do not provide conclusive information about the long run implications for wage inequality.

The model is related to the older literature on the diffusion of new technologies, including the work of Griliches (1957), Mansfield (1961), David (1969), Stoneman (1976), and Davies (1979), who argue that the costs of new technologies are important determinants of adoption and diffusion. ${ }^{3}$ In this paper, (endogenous) wages and productivity gains determine whether computer adoption is beneficial, whereas previous models treated the determinants of the diffusion process mostly exogenously. The model is also related to more recent studies on technology adoption by Chari and Hopenhayen (1991), Galor and Tsiddon

\footnotetext{
${ }^{3}$ See Geroski (2000) for an overview of the technology diffusion literature.
} 
(1997), Caselli (1999), and Weinberg (2001). ${ }^{4}$ In these papers, skilled workers have a higher probability to work with new technologies than unskilled workers because new technologies can be more productively operated by skilled workers, but they do not take into account the costs of new technologies. Violante (2002) assumes noncompetitive labor markets to explain wage inequality among ex ante equal workers in relation to the adoption of new technologies. The heterogeneity among workers is not generated by skill differentials but by technological differentials across the machines of different vintages they are matched with. We are able to distinguish between the timing of technology adoption and the productivity gain resulting from adoption in a competitive labor market. By distinguishing productivity differentials within the groups of skilled and unskilled workers, we also differ from the above theories, and the ones developed by Greenwood and Yorukoglu (1997), Acemoglu (1998), and Kiley (1999), by explaining both between-group and within-group wage inequality, whereas the other studies mentioned above only analyze wage inequality either within or between groups. ${ }^{5}$ Finally, with regard to the distribution of productivity within the groups of skilled and unskilled workers, this paper is related to the approaches of Heckman, Lochner and Taber (1998), Galor and Moav (2000), Gould, Moav and Weinberg (2001), and Aghion, Howitt and Violante (2002). They also use some (ability) distribution to examine within-group inequality, which leads to the development and transferability of technology-specific skills driving wage inequality, whereas our mechanism of within-group inequality is determined by the costs of computers relative to the wages and the productivity gains from using computers. Finally, the

\footnotetext{
${ }^{4}$ The models predicting the adoption and diffusion of general purpose technologies are also consistent with our approach because computer use is pervasive in a wide range of sectors in ways that change their modes of production (e.g., Bresnahan and Trajtenberg, 1995 and Helpman and Trajtenberg, 1998).

${ }^{5}$ Caroli and García-Peñalosa (2002) also present a model accounting for both between-group and within-group wage inequality using differences in wage-setting behavior and wage instability in different stages of technological development. Their model is driven by the assumption that changes in workers' risk aversion induce changes in wages.
} 
pattern of wage inequality resulting from the diffusion of computers presented in this paper is not necessarily caused by a pervasive skill-biased nature of computers, but driven by the adoption of computers at different points in time.

The plan of the paper is as follows. Section 2 presents the patterns of wage inequality in the United States. Section 3 presents the basic model. Section 4 shows the predicted pattern of wage inequality over time. Section 5 presents estimates of the model for wage inequality in the United States in the period 1963-2000. Section 6 concludes.

\section{Changes in the U.S. Wage Structure, 1963-2000}

If computer adoption increases productivity, two factors influencing the wage structure have to be distinguished. First, there will be an individual productivity increase for workers adopting computers. Secondly, increased productivity also increases the supply of goods produced. This latter factor might influence the wages of all workers, depending on how substitutable the goods they produce are. Hence, besides an individual effect, related to productivity, changes in the wage structure depend on the composition of groups of workers producing substitutable goods. We define wage differences between workers with different productivity levels producing similar goods as within-group wage inequality and define wage differences between workers in different product market groups as between-group wage inequality.

Since it is difficult to determine exactly the groups of workers producing similar goods, we assume that the main distinction in the goods market can be made between physical and cognitive goods and services. We assume that physical goods are produced by unskilled workers, while cognitive goods are produced by skilled workers. Skilled workers are defined as those with a college degree or more, and unskilled workers as the ones with a level of 
education below a college degree. Workers are assumed to be fully substitutable within these two groups, and substitutable in a limited way or complementary between groups.

Figure 1 shows three pictures of relative annual wages in the United States in the period 1963-2000 using the March CPS files. ${ }^{6}$ Each picture provides annual wages relative to the annual wages of the workers at the $10^{\text {th }}$ percentile of the unskilled wage distribution. Comparison of Panel A and B reveals information about the pattern of within-group wage inequality for skilled workers. The figures reveal that within-group wage inequality for skilled workers is increasing throughout the whole period but that the behavior of the top and bottom percentiles is rather different. Panel C shows within-group wage inequality for unskilled workers. This picture shows a rather modest increase until 1980 and an acceleration afterwards. To examine between-group wage inequality between skilled and unskilled workers, Panel A and B have to be compared with Panel C of Figure 1. This comparison yields that the wages of the top earners among the skilled workers are steadily increasing over time, but that the wages of the bottom earners among the skilled workers are first falling and then rising again.

\section{INSERT FIGURE 1 OVER HERE}

To show the crucial distinction between the development of between-group and within-group wage inequality, we compare workers from both groups earning the same wages in $1963 .{ }^{7}$ We have taken the annual wages of the skilled workers at the $40^{\text {th }}$ and $50^{\text {th }}$ percentile and looked for the unskilled workers earning the same annual wages. It turns out that these are the wages of the unskilled workers at the $75.7^{\text {th }}$ and $83.9^{\text {th }}$ percentile of the unskilled wage

\footnotetext{
${ }^{6}$ See Appendices A.1-A.5 for details concerning the data.

${ }^{7}$ We are grateful to Kevin Murphy for his suggestion to perform this analysis.
} 
distribution. ${ }^{8}$ Figure 2 shows the wage differentials between both groups keeping the relative position within each group constant at these percentiles. The picture reveals that wage differentials rise somewhat and are positive until the early 1970s. From then on until the mid1980s the wages for unskilled workers are higher. Around 1980 there is a turning point in the wage differential in favor of skilled workers. Figure 2 reveals that workers with the same productivity in 1963, but who differ with respect to the group they belong to, have experienced a different pattern of wages over time. ${ }^{9}$

\section{INSERT FIGURE 2 OVER HERE}

\section{Basic Model}

Analyzing these simple pictures suggests that wages are both determined by individual productivity levels within each group of workers and by differences between the two groups of workers. These two effects have a different impact on the wage structure over time and need to be analyzed separately. ${ }^{10}$ To do so, consider a competitive economy producing a homogeneous good $Y$. The good is produced by a labor input consisting of skilled and unskilled workers. Because of productivity differences among skilled and unskilled workers, we define the supply in terms of efficiency units as $S$ and $U$.

\footnotetext{
${ }^{8}$ These percentiles of the wage distribution of both groups are taken because at these percentiles there exists a great deal of overlap between the wages of both groups of workers. The percentiles do not exactly match because not all possible values of wages are present in the sample. Actually the $75.7^{\text {h }}$ and $83.9^{\text {h }}$ percentile of the unskilled wage distribution are somewhat above the $40^{\text {th }}$ and $50^{\text {th }}$ percentile of the skilled wage distribution.

${ }^{9}$ This pattern of between-group wage inequality is consistent with the figures presented by Katz and Murphy (1992) using similar data for the period 1963-1987, and the analysis of Krusell, Ohanian, Ríos-Rull and Violante (2000) for the period 1963-1992.

${ }^{10}$ Such arguments have also been put forward by Card and DiNardo (2002). They argue that the effects of computer adoption on the wage structure need to be different for different groups of workers at different points in time to be able to connect the structure of wages over the last 50 years to computerization.
} 


\section{Production}

Production occurs according to a CES production function and equals

$$
Y=\left((\chi S)^{\rho}+(\psi U)^{\rho}\right)^{1 / \rho}
$$

where $\rho \leq 1$, and the elasticity of substitution between $S$ and $U$ equals $\sigma=1 /(1-\rho)$. The corresponding wages in efficiency units are $w_{s}^{e u}$ and $w_{u}^{e u}$ for $S$ and $U$, and competitive wages give a standard relative demand equation:

$$
w^{e u} \equiv \frac{w_{s}^{e u}}{w_{u}^{e u}}=\left(\frac{\psi U}{\chi S}\right)^{1 / \sigma} .
$$

For convenience, $w_{u}^{e u}$ is normalized to 1 , so $w_{s}^{e u}=(\chi S / \psi U)^{1-\rho}$.

\section{Heterogeneity among Workers}

Productivity levels differ not only between groups, but also within both groups. This might be due to unobserved heterogeneity, but individual productivity levels might also differ from year to year due to on-the-job learning, aging, sector shifts and other influences, which need not be specified further. We assume that workers are perfectly substitutable within both groups, so any productivity difference is reflected in wages. ${ }^{11}$

Productivity depends on the parameters $a_{i} \sim[\underline{\alpha}, \bar{\alpha}]$ with $\bar{\alpha}>\underline{\alpha}$ for skilled worker $i$ and $b_{j} \sim[\underline{\beta}, \bar{\beta}]$ with $\bar{\beta}>\underline{\beta}$ for unskilled worker $j$. Productivity parameters of skilled and unskilled workers can only be compared when wages in efficiency units are taken into account. We allow the wage intervals of both groups to overlap. This is consistent with the empirical observation that the wages of the most productive unskilled workers are higher than

\footnotetext{
${ }^{11}$ Gould, Moav and Weinberg (2001), Aghion, Howitt and Violante (2002), and Violante (2002) also explain differences in the development of within-group and between-group wage inequality in the United States. They assume workers to differ in their adaptability to new technologies as a result of random shocks or assignment, and Violante (2002) also assumes that technologies differ in their productivity or quality to generate temporary within-group wage inequality. Aghion, Howitt and Violante (2002) use an overlapping generations model to get similar effects of technology adoption on wages. Caroli and García-Peñalosa (2002) build a model in which they use different attitudes towards risk to generate heterogeneity between workers.
} 
the wages of the least productive unskilled worker, i.e. $\bar{\beta} w_{u}^{e u}>\underline{\alpha} w_{s}^{e u}$. To make this overlap of productivity levels consistent with rational individual schooling decisions, it has to be assumed that productivity does not only depend on years of schooling. Differences in innate ability, talent for either physical or cognitive tasks, or age and experience all provide plausible arguments for this assumption.

To enable an analytical solution of the model, the distribution of the productivity parameters for skilled and unskilled workers is assumed to take the following form: $P^{s}(a)=\frac{1}{1-\rho} a^{\frac{2 \rho-1}{1-\rho}} p^{s}$ and $P^{u}(b)=\frac{1}{1-\rho} b^{\frac{2 \rho-1}{1-\rho}} p^{u}$, where $\quad p^{s}=\frac{\sigma-1}{\sigma} \frac{1}{\bar{\alpha}^{\sigma-1}-\underline{\alpha}^{\sigma-1}}$ and $p^{u}=\frac{\sigma-1}{\sigma} \frac{1}{\bar{\beta}^{\sigma-1}-\underline{\underline{\beta}}^{\sigma-1}}$ are obtained from solving the integral for the distributions of productivity parameters of both types of workers. If $\sigma=2$, the assumed distribution is such that the wage bill is uniformly distributed over the productivity parameters $a$ and $b{ }^{12}$

\section{Productivity}

Each worker's productivity level depends on his productivity parameter and whether or not he uses a computer. Productivity equals $q_{i}^{s}=a_{i}$ and $q_{j}{ }^{u}=b_{j} \quad$ without using a computer and $q_{i}^{s}=a_{i} \theta^{s}$ and $q_{j}^{u}=b_{j} \theta^{u}$ when using a computer, where $\theta^{s}, \theta^{u}>1$ is the proportional productivity gain from working with a computer. We assume that within both groups the productivity gain from using a computer is the same, while between both groups it is allowed to differ, and for all workers there exists some computer application, which makes production more efficient. ${ }^{13}$ These assumptions are justified because within each group, workers are

\footnotetext{
${ }^{12}$ For the production function used here, a different elasticity of substitution between skilled and unskilled workers could lead to a slightly different distribution of the productivity parameters.

${ }^{13}$ The alternative assumption would be a complementary relationship between the productivity parameters $a$ and $b$ and $\theta$. Assuming such a relationship leads to earlier adoption of computers (given the costs of adoption) for workers with a proportional productivity gain $\theta^{i}>\theta^{s}$ and $\theta^{j}>\theta^{u}$ and to a later adoption for workers experiencing proportional productivity gains smaller than $\theta^{s}$ and $\theta^{u}$. As will be shown below, such an assumption would lead to a similar pattern of diffusion but to a permanently higher level of within-group wage inequality.
} 
producing the same product.

\section{Wages}

In a competitive labor market, each efficiency unit of labor receives the same return and the individual wage equals the productivity parameter multiplied by the return to an efficiency unit of labor. In such a setting, employers are indifferent between employing a worker who uses a computer and one who does not because they pay the same wage for each efficiency unit of labor. This means that both the productivity gain and the costs of the computer are passed on to worker. Hence, wages equal $w_{i}^{s}=a_{i} w_{s}{ }^{e u}$ and $w_{j}{ }^{u}=b_{j}$ for a worker who does not use a computer and $w_{i}^{s}=a_{i} w_{s}^{e u} \theta^{s}-V$ and $w_{j}^{u}=b_{j} \theta^{u}-V$ for one who does, where $V$ represents the cost of the computer. Note that $V$ is (implicitly) expressed in terms of $w_{u}^{e u}$.

\section{Wages and Computer Adoption}

The decision to adopt a computer can be written as a trade-off between the increased productivity $\theta$ and the costs of the computer $V$, given the worker's productivity. ${ }^{14}$ The breakeven productivity for computer adoption for both types of workers then equals

and

$$
a_{i}^{b e}=\frac{V}{\left(\theta^{s}-1\right) w_{s}^{e u}}
$$

$$
b_{j}^{b e}=\frac{V}{\left(\theta^{u}-1\right)} .
$$

Equations (3) show that the break-even productivity at which it becomes beneficial to adopt a computer falls when (i) the costs of the computer fall, (ii) the productivity gain becomes

\footnotetext{
${ }^{14}$ Note that the adoption decision may be different for each individual worker within a firm. This is consistent with the literature investigating inter- and intra-firm technology diffusion showing that the diffusion of new technology within firms is similar to the diffusion between firms (e.g., Karshenas and Stoneman, 1993 and Stoneman and Kwon, 1996). Hence, it is unlikely that firms adopt computers for all workers at once.
} 
larger, and (iii) the wage per efficiency unit of labor is higher. Assuming that the costs of the computer are the same for each worker and fall exogenously and continuously over time, the productivity gain and the wage in terms of efficiency units determine the adoption of the computer. ${ }^{15}$ Hence, computer costs relative to wages determine whether or not it is beneficial for a worker to adopt a computer while differences in computer use between skilled and unskilled workers also depend on differences in the proportional productivity gains from using a computer. ${ }^{16}$

\section{Supply of Efficiency Units}

The supply of efficiency units of labor consists of two components: (i) the sum of all productivity parameters representing total productivity before computerization, and (ii) the productivity gains workers experience from using a computer, which equals

$$
S=S^{e} \int_{\underline{\alpha}}^{\bar{\alpha}} a_{i} P^{s} d a_{i}+S^{e} \int_{a_{i}^{b e}}^{\bar{\alpha}}\left(\theta^{s}-1\right) a_{i} P^{s} d a_{i} \quad \text { and } \quad U=U^{e} \int_{\underline{\beta}}^{\bar{\beta}} b_{j} P^{u} d b_{i}+U^{e} \int_{b_{j}^{b e}}^{\bar{\beta}}\left(\theta^{u}-1\right) b_{j} P^{u} d b_{j} \text {, }
$$

where $S^{e}$ and $U^{e}$ are defined as the supply of skilled and unskilled workers in persons.

Solving these equations results in the following two expressions for the supply of efficiency units of labor:

$$
S=S^{e} p^{s}\left(\left(\bar{\alpha}^{\sigma}-\underline{\alpha}^{\sigma}\right)+\left(\theta^{s}-1\right)\left(\bar{\alpha}^{\sigma}-\left(\frac{V}{\left(\theta^{s}-1\right) w_{s}^{e u}}\right)^{\sigma}\right)\right)
$$

and

\footnotetext{
${ }^{15}$ The development of computers might also be endogenized by directing a certain fraction of production towards the development of computers. The allocation of labor to R\&D then leads to falling costs and higher quality. However, endogenizing the development of computers does not yield additional insight in explaining wage inequality. David and Olsen (1986) develop such a diffusion model in which the development of new technology is endogenized. Earlier attempts to endogenize the development of new technologies can be found in e.g., Griliches (1957, 1958), and Mansfield $(1961,1965)$.

${ }^{16}$ If, all things being equal, $\theta^{s}-1>\theta^{u}-1$, skilled workers gain more in terms of productivity from using a computer, which is equivalent to arguing that they are more efficient in using the computer. Chennells and Van Reenen (1997), Entorf and Kramarz (1997), and Entorf, Gollac and Kramarz (1999) interpret their findings for the United Kingdom and France of high-wage workers using a computer as results in favor of such an explanation.
} 


$$
U=U^{e} p^{u}\left(\left(\bar{\beta}^{\sigma}-\underline{\beta}^{\sigma}\right)+\left(\theta^{u}-1\right)\left(\bar{\beta}^{\sigma}-\left(\frac{V}{\left(\theta^{u}-1\right)}\right)^{\sigma}\right)\right) .
$$

Equations (4) show that the supply of efficiency units of labor depends positively on the size of the distribution of the productivity parameters $a$ and $b$, the productivity gain from using a computer $\theta$, and the elasticity of substitution between skilled and unskilled workers $\sigma$, and negatively on the costs of the computer $V$.

\section{Relative Wages after Complete Diffusion with No Computer Costs}

To solve the equilibrium relative wages in efficiency units, equations (4) are substituted into the relative demand equation (2).

Before turning to the equilibrium wages, consider relative wages after the complete diffusion of computers and $V=0$ :

$$
\frac{\bar{w}_{s}}{\bar{w}_{u}}=\left(\frac{\theta^{s}}{\theta^{u}}\right)^{\rho} \frac{\bar{w}_{s}^{0}}{\bar{w}_{u}^{0}} .
$$

Equation (5) shows that relative wages after diffusion have changed with a factor $\left(\theta^{s} / \theta^{u}\right)^{\rho}$. Wage inequality will be higher if $\theta^{s}<\theta^{u}$ and skilled and unskilled workers are complements $(\rho<0)$ and if $\theta^{s}>\theta^{u}$ and skilled and unskilled workers are substitutes $(\rho>0)$. While the empirical literature seems to point at $\rho>0,{ }^{17}$ the model leaves open both alternatives. ${ }^{18}$

\section{Computer costs}

Of course, the costs of using a computer are not negligible relative to the wage. The costs of

\footnotetext{
${ }^{17}$ See e.g., Katz and Murphy (1992) and Johnson (1997) for U.S. estimates, Angrist (1995) for estimates for Israel, and Hamermesh (1993) for an overview.

${ }^{18}$ An instance at which $\rho<0$, often pointed at, is the complementarity between the manager and the secretary. If $\theta^{s}<\theta^{u}$ the secretary benefits more from computer use than the manager. This means that, given the amount of work, the demand for secretaries will fall.
} 
the computer should be interpreted as the costs of the entire deal, i.e. hardware, software, networks, and technical assistance. In dollar terms, a back-of-the-envelope calculation estimates the annual costs of using a computer to be $\$ 6,567$ in 1997 , which accounts for about 21 percent of the average worker's real annual wage in the United States. This figure is computed as follows.

First, using the "investment in information processing equipment and software" data collected by NIPA and dividing this number by the computer using workforce in full-time equivalents ${ }^{19}$ yields computer costs of $\$ 4,530 .^{20}$ Secondly, regressing the relative number of workers in computer related jobs $(c w)^{21}$ to computer users $(c)$ per sector of industry, using the October 1997 School Enrollment Supplements to the CPS, and weighing by industry size, yields (standard errors in brackets) $c w=-1.38(.003)+.063(.005) c$. To obtain a conservative estimate for the cost of technical assistance, we left out the sectors of industry with relatively high fractions of computer related job. ${ }^{22}$ Since the average monthly wages of workers in

\footnotetext{
${ }^{19}$ Full-time equivalent employees equal the number of employees on full-time schedules plus the number of employees on part-time schedules converted to a full-time basis. The number of full-time equivalent employees in each industry is the product of the total number of employees and the ratio of average weekly hours per employee for all employees to the average weekly hours per employee on full-time schedules.
}

${ }^{20}$ Autor, Katz and Krueger (1998) report computer investments per full time equivalent worker to be $\$ 2,545$ in 1990 , which is equivalent to about $\$ 5,000$ per full time equivalent computer user. Figures for 1960,1970 and 1980 yield comparable investments per full-time equivalent computer user. Computer use is taken from the October 1997 School Enrollment Supplements to the CPS. There is likely to be measurement error in the NIPA data because the Bureau of Economic Analysis does often not directly measure information processing equipment and software at high frequency, but imputes these data. See Gorman, Musgrave, Silverstein and Comins (1985), Berndt and Morrison (1995), and Autor, Katz and Krueger (1998) for a discussion. See also Allen (2001) for a more detailed treatment of computer investments and investments in science and technology related to the wage structure in the United States.

${ }^{21}$ These occupations are "Computer systems analysts and scientists" (CPS Occupational Classification Code for Detailed Occupational Categories 064), "Operations and systems researchers and analysts" (065), "Computer science teachers" (129), "Computer programmers" (229), "Tool programmers, numerical control" (233), "Computer operators" (308), "Peripheral equipment operators" (309), "Data-entry keyers" (385), "Data processing equipment repairers" (525), and "Office machine repairers" (538).

${ }^{22}$ Sectors of industry with more than 10 percent computer related employment are "Computer and data processing services" (CPS Industry Classification Code for Detailed Industry 732), "Telegraph and miscellaneous communications services" (442), "Not specified utilities" (472), "Computers and related 
computer related jobs equals $\$ 2,692$, we estimate the costs of assistance for each individual worker to be equal to $\$ 2,037$.

It has been well documented that the price of computer equipment has been falling extremely rapidly over time, which induced diffusion (e.g., Jorgenson and Stiroh, 1999 and Jorgenson, 2001). Figures collected by NIPA suggest that investments in computer equipment are only some $20-25$ percent of total investments in information processing equipment and software over the 1990s. Investments in software account for some 30-40 percent, while other investments make up some 35-50 percent of total investments. The quality-adjusted prices of software (e.g., Jorgenson, 2001, Figure 2), and other computer related investments have hardly been falling over time. The overall annual decline in the costs of information processing equipment and software has been 2.1 percent over the period $1959-2001 .{ }^{23}$ These figures suggest that the adoption rate of computers at work is likely to be slower than the rate of fall in the price of computer equipment, and that the costs of computers are non-negligible relative to the workers' wages.

Differences in the quality of computers used by different workers are not explicitly considered in the model. When considering different vintages of computers in a perfectly competitive market, the most productive workers would be assigned to the most recent vintage. In addition, the costs of the computer might also be different for different workers. For example, large firms might have an advantage in maintenance and technical assistance, which leads to lower computer costs per worker. Next to that, some workers need a less expensive computer than others, which induces earlier adoption, all other things equal.

equipment" (322), "Electrical repair shops" (752), "Professional and commercial equipment and supplies" (510), and "Radio, TV, and computer stores" (633).

${ }^{23}$ These numbers and calculations are based on NIPA figures and consistent with the number and calculations presented by Jorgenson (2001). 
Finally, some workers perform tasks on the basis of ready-made applications, whereas for others with higher wages and higher productivity gains no application is available yet. However, for simplicity, we make the assumption that the costs of the computer are given to the worker and are equal for all workers.

\section{Equilibrium Relative Wages in Efficiency Units}

With an exogenously falling price of computers, the benefits of adopting a computer are changing over time for all workers. Since the productivity levels of both skilled and unskilled workers is concentrated on the intervals parameters $[\underline{\alpha}, \bar{\alpha}]$ and $[\underline{\beta}, \bar{\beta}]$, different stages in the adoption process will occur. The order of these stages depends on both the level of wages and break-even wages of skilled and unskilled workers. Since a diffusion pattern in which the most productive skilled workers are the first to adopt - followed by the most productive unskilled workers, the least productive skilled workers, and finally the least productive unskilled workers - seems to be consistent with the actual patterns of adoption, our analyses focus on this sequence of adoption. ${ }^{24}$

Equilibrium wages in efficiency units are computed in each of the five stages in the diffusion process: $:^{25}$ (i) no computer use, (ii) the high-wage skilled workers adopt computers, (iii) both types of workers adopt computers, (iv) all skilled and a fraction of the unskilled workers adopt computers, and (v) all workers use computers. Table 1 shows the relative

\footnotetext{
${ }^{24}$ This assumption is consistent with the figures on computer use for 1984, 1989, and 1993 presented by Autor, Katz and Krueger (1998). They show that computer use is higher for more educated workers but it is rising among all different educational groups.

${ }^{25}$ Note that it is possible that certain stages of diffusion will never become effective because of the overlapping productivity parameters between skilled and unskilled workers. For example, given wages, proportional productivity gains and the distribution of productivity parameters, an unskilled worker with productivity

$\bar{\beta}$ could reach the break-even point for computer use later than a skilled worker with productivity $\underline{\alpha}$, which would induce computer use among unskilled workers when all skilled workers already have one. Therefore, in theory, the order of the stages could be different.
} 
wages in efficiency units in each of the five stages. When there is no computer use, relative wages depend on the supply of efficiency units, the distribution of productivity parameters and the elasticity of substitution between skilled and unskilled labor. In the other four stages, relative wages in efficiency units also depend on $\theta, V$, and the additional units of supply of efficiency units. Note that relative wages in efficiency units do not change anymore once every worker has adopted a computer, even when $V>0$. This is because the supply of the number of efficiency units of labor, once all workers have adopted a computer, remains constant and is independent of $V$, e.g. equations (4).

\section{INSERT TABLE 1 OVER HERE}

Table 2 shows individual wages for two workers with productivity parameters $a_{1}$ and $a_{2}$ relative to worker $j$ with productivity $\underline{\beta}$. The level of the wages in efficiency units and the size of the proportional productivity gain are assumed in such a way that the adoption of computers is assumed to take place in the following order: $\bar{\alpha}, a_{1}, \bar{\beta}, \underline{\alpha}, \underline{\beta}$ and $\bar{\alpha}, \bar{\beta}, a_{2}, \underline{\alpha}, \underline{\beta}$. From Table 2 it becomes clear that the wages of all workers are influenced once the first worker adopts a computer. In addition, once every workers has adopted a computer, it is not until $V=0$ that wages do not change any more (stage 6$){ }^{26}$

\section{INSERT TABLE 2 OVER HERE}

\section{Pattern of Relative Wages over Time}

\section{Within-Group Wage Inequality}

The individual wages in Table 2 can be used to analyze the properties of within-group wage inequality over time. Figure 3 provides the wage pattern that results from the model for skilled

\footnotetext{
26 The equilibrium wages for other skilled workers with different productivity parameters follow straightforwardly from the results presented in Table 2. In addition, the derivation of the wages for unskilled workers is similar to the derivation of the equilibrium wages shown here.
} 
(Panel A) and unskilled (Panel B) workers. Since no worker has adopted a computer yet, in the first stage of the model all wage differentials remain the same. The wage structure starts to change when $V$ is sufficiently low for the most productive skilled workers to adopt a computer. In this second stage (which lasts until the most productive unskilled worker adopts a computer), the wages of skilled workers change when skilled worker $l$ adopts a computer $\left(a_{l}\left(\theta^{s}-1\right) w_{s}^{e u}=V\right)$ according to

$$
\frac{\partial w_{k} / \partial-V}{a_{k}}=\frac{1}{a_{k}}-\frac{a_{l}^{\sigma-1} \theta^{s}}{\theta^{s} \bar{\alpha}^{\sigma}-\underline{\alpha}^{\sigma}}
$$

for skilled workers $k$ who already adopted a computer $\left(a_{k} \geq a_{l}\right)$, and according to

$$
\frac{\partial w_{m} / \partial-V}{a_{m}}=-\frac{a_{l}^{\sigma-1}}{\theta^{s} \bar{\alpha}^{\sigma}-\underline{\alpha}^{\sigma}}
$$

for skilled workers $m$ who did not yet adopt $\left(a_{m}<a_{l}\right)$.

From equations (6) a number of model features become apparent. First, once it becomes beneficial for worker $l$ to adopt a computer his wage increases relative to the wage of worker $m$ leading to wage inequality within the group of skilled workers because $\frac{\partial w_{l} / \partial-V}{a_{l}}>\frac{\partial w_{m} / \partial-V}{a_{m}} \cdot{ }^{27}$ The wages for the non-adopters change, but only proportionally, and there is no increase in wage inequality between non-adopters. Since the term $1 / a_{k}$ is larger for lower values of $a_{k}$ there is wage convergence within the group of computer users, leading to

\footnotetext{
${ }^{27}$ If $\theta$ is high relative to $V$, adoption of the whole group will occur at earlier stages. It will also lead to a higher maximum level of within-group wage inequality because $\alpha \theta^{s t}-V-\underline{\alpha}>\alpha \theta^{s L}-V-\underline{\alpha}$ if $\theta^{s 1}>\theta^{s 2}$. The maximum level of wage inequality will be experienced earlier because the least productive worker will reach the break-even point of adoption earlier on. On the other hand, $V$ becomes negligible relative to the wage costs earlier on, which leads to a faster drop in within-group wage inequality. If $V$ falls faster over time, the adoption of computers and the effects on the wage structure will occur faster and earlier on. The maximum level of within-group wage inequality will remain the same because this only depends on $\bar{\alpha}-\underline{\alpha}$ and $\theta^{s}$.
} 
less wage inequality among computer users in the same group.

Secondly, it is not necessarily the case that the wages of computer adopters rise immediately after adoption. Wages fall, relative to worker $j$ with productivity $\underline{\beta}$, for the first adopter $\bar{\alpha}$ because $\frac{\partial w_{\bar{\alpha}}}{\partial-V}=1-\frac{\bar{\alpha}^{\sigma} \theta^{s}}{\theta^{s} \bar{\alpha}^{\sigma}-\underline{\alpha}^{\sigma}}<0$. However, the wages for the workers not adopting a computer fall by more because $a_{k}^{\sigma} \theta^{s}-\left(\theta^{s} \bar{\alpha}^{\sigma}-\underline{\alpha}^{\sigma}\right)<a_{k}^{\sigma-1} a_{l}$, so it is rational to adopt a computer at the break-even point (e.g., equations (3)). In this stage of the diffusion process, wages rise immediately after adoption only if equation (6a) is positive. This situation might never occur in this stage but is more likely to occur if $\bar{\alpha}-\underline{\alpha}$ is relatively large. ${ }^{28}$

If $\frac{\partial w_{a_{l}}}{\partial-V}=1-\frac{a_{l}^{\sigma} \theta^{s}}{\theta^{s} \bar{\alpha}^{\sigma}-\underline{-}^{\sigma}}=0$ wages for worker $l$ rise immediately after adoption. Note that, because $1 / a_{k}<1 / a_{l}$, the wages for worker $k$ are still falling, relative to $\underline{\beta}$, at this point in time. Wages of computer users and non-users are still diverging, but at a lower pace, because when skilled and unskilled workers are substitutes $(\sigma \geq 1) a_{l}^{\sigma-1}$ decreases when $\alpha_{l}$ decreases.

In the third stage, when unskilled workers start to adopt computers $\left(\bar{b}\left(\theta^{u}-1\right) w_{u}^{e u}=V\right)$, the wage development of skilled workers when worker $l$ adopts a computer $\left(a_{l}\left(\theta^{s}-1\right) w_{s}^{e u}=V\right)$ can be described by

$$
\frac{\partial w_{k} / \partial-V}{a_{k}}=\frac{1}{a_{k}}-\frac{a_{l}^{\sigma-1} \theta^{s}}{\theta^{s} \bar{\alpha}^{\sigma}-\underline{\alpha}^{\sigma}}+\left(\frac{\psi U^{e} p^{u}}{\chi S^{e} p^{s}}\right)\left(\frac{\theta^{s}-1}{\theta^{u}-1}\right)^{\sigma-1} \frac{a_{l}^{\sigma-1} \theta^{s}}{\theta^{s} \bar{\alpha}^{\sigma}-\underline{\alpha}^{\sigma}}
$$

for skilled workers $k$ who already adopted a computer $\left(a_{k} \geq a_{l}\right)$, and by

\footnotetext{
${ }^{28}$ The pattern and length of time of within-group wage inequality also depend on the productivity differential $\alpha-\underline{\alpha}$, the costs of the computer relative to the productivity gain, and the speed at which $V$ is falling over time. The maximum level of within-group wage inequality only depends on $\alpha-\underline{\alpha}$ and $\theta^{s}$. When the initial productivity differential is smaller, or the productivity gain relative to the computer cost is higher, or $V$ is falling more rapidly over time, the length of time of increasing and overall within-group wage inequality is shorter. A higher productivity differentials and a higher proportional productivity gain will induce a higher maximum absolute level of within-group wage inequality.
} 


$$
\frac{\partial w_{m} / \partial-V}{a_{m}}=-\frac{a_{l}^{\sigma-1}}{\theta^{s} \bar{\alpha}^{\sigma}-\underline{\alpha}^{\sigma}}+\left(\frac{\psi U^{e} p^{u}}{\chi S^{e} p^{s}}\right)\left(\frac{\theta^{s}-1}{\theta^{u}-1}\right)^{\sigma-1} \frac{a_{l}^{\sigma-1}}{\theta^{s} \bar{\alpha}^{\sigma}-\underline{\alpha}^{\sigma}}
$$

for skilled workers $m$ who did not yet adopt $\left(a_{m}<a_{l}\right)$.

If skilled and unskilled labor are substitutes, both the skilled computer users and the skilled non-users benefit from the increased productivity among unskilled workers, reflected in additional term in equations (7) when compared to equations (6). Due to the increased productivity of skilled computer users, these workers gain more in relative terms than the skilled non-users. Computer use among unskilled workers therefore stimulate the increasing within-group wage inequality among skilled workers. Note that the development of relative wages of two computer users or of two non-users are not affected by computer adoption among unskilled workers.

In the fourth stage, all skilled workers have adopted the computer. Until adoption is completed among unskilled workers (stage 5), the wage developments for skilled workers are described by

$$
\frac{\partial w_{k} / \partial-V}{a_{k}}=\frac{1}{a_{k}}+\left(\frac{\left(\theta^{u}-1\right)}{\left(\theta^{s}-1\right)}\right)^{1-\sigma} \frac{\psi U^{e} p^{u} \theta^{s} a^{b e^{\sigma-1}}}{\chi S^{e} p^{s} \theta^{s}\left(\bar{\alpha}^{\sigma}-\underline{\alpha}^{\sigma}\right)} .
$$

From equation (8) it follows that if all skilled workers have adopted a computer, but not all unskilled workers have adopted one yet, there will be wage convergence within the group of skilled workers because $\frac{1}{\bar{\alpha}}<\frac{1}{\underline{\alpha}}$.

If all workers have adopted computers, $\frac{\partial w_{k} / \partial-V}{a_{k}}=\frac{1}{a_{k}}$, so it follows straightforwardly that wage inequality within the group of skilled workers behaves similarly to the previous situation. Finally, if $V=0$, wage inequality within the group of skilled workers is back at its 
level prior to computerization.

\section{INSERT FIGURE 3 OVER HERE}

A similar pattern of wage inequality within the group of unskilled workers can be obtained. The only difference is that the timing of the different stages of adoption is different. Essentially, the wage structure within both groups is characterized by only three phases: (i) no computer use, (ii) some computer use, and (iii) every workers uses a computer. Only when unskilled workers start to adopt computers, the adoption process of skilled workers, and therefore within-group wage inequality accelerates because of the increase in skilled workers' efficiency wages. Such increasing wages are equivalent to faster decreasing computer prices, since the wage/computer price ratio determines the adoption process.

\section{Between-Group Wage Inequality}

Defining the wage ratio of the workers with productivity $\bar{\alpha}$ and $\underline{\beta}$ as between-group wage inequality, it follows from equations (6) that this ratio is falling when the first skilled worker adopts a computer, leading to a lower level of between-group wage inequality.

Between-group wage inequality continues to fall until $\frac{\partial w_{a_{i}}}{\partial-V}=0$, where $\bar{\alpha}>a_{i}$ or until the first unskilled worker adopts a computer. Between-group wage inequality then increases because of two effects. The first effect results from benefits of the falling costs of computer use for skilled workers, and the second effect results from the increasing supply of efficiency units of unskilled labor after computer adoption, which depresses the unskilled wages in efficiency units. Note that these effects do not depend on differences between $\theta^{s}$ and $\theta^{u}$.

The development of between-group wage inequality in each stage of computer adoption and diffusion is displayed in Figure 4. The figure reveals that between-group wage inequality is not likely to increase after the first workers have adopted computers. Only when 
a non-negligible group of skilled workers or the first unskilled workers adopt computers, between-group wage inequality starts to rise. This is consistent with Bresnahan's (1999) concern about many workers already using computers without any substantial rise in wage inequality as a result of computer adoption in the 1970s. The figure also shows that the pattern of between-group wage inequality is leveling off at the end of stage 3 and again at the end of stage 4 . At the end of stage 3 almost all skilled workers have adopted computers, which seems to be the case in the late 1990s. And at the end of stage 4 all workers have adopted computers. The leveling off of between-group wage inequality in the mid-1990s, pointed at by Card and DiNardo (2002) is therefore consistent with our model. Final wage inequality (when $V=0$ ) is described by equation (5).

Between-group wage inequality reaches its maximum level at the point where the least productive unskilled worker is just about to adopt a computer. At that point, the wage of the worker with productivity $\bar{\alpha}$ equals

$$
w_{\bar{\alpha}}^{c}=\frac{1}{\underline{\beta}}\left(\left(\frac{\psi U^{e} p^{u} \theta^{u}\left(\bar{\beta}^{\sigma}-\underline{\beta}^{\sigma}\right)}{\chi S^{e} p^{s} \theta^{s}\left(\bar{\alpha}^{\sigma}-\underline{\alpha}^{\sigma}\right)}\right)^{\frac{1}{\sigma}} \bar{\alpha} \theta^{s}-\underline{\beta}\left(\theta^{u}-1\right)\right)
$$

compared to

$$
w_{\bar{\alpha}}^{n c}=\frac{\bar{\alpha}}{\underline{\beta}}\left(\frac{\psi U^{e} p^{u}\left(\bar{\beta}^{\sigma}-\underline{\beta}^{\sigma}\right)}{\chi S^{e} p^{s}\left(\bar{\alpha}^{\sigma}-\underline{\alpha}^{\sigma}\right)}\right)^{\frac{1}{\sigma}}
$$

before computerization. The ratio of these two wages equals

$$
\frac{w_{\bar{\alpha}}^{c}}{w_{\bar{\alpha}}^{n c}}=\left(\frac{\theta^{u}}{\theta^{s}}\right)^{\frac{1}{\sigma}} \theta^{s}-\frac{\underline{\beta}\left(\theta^{u}-1\right)}{w_{\bar{\alpha}}^{n c}} .
$$


Equation (11) has a number of interesting properties. First, the ratio of wages is increasing in $w_{\bar{\alpha}}^{n c}$ meaning that a higher level of initial wage inequality between the most and least productive worker leads to a higher peak in between-group wage inequality. Secondly, it is also increasing in $\theta^{s}$ for $\rho>0$, which means that a higher productivity gain for skilled workers leads to a higher maximum level of between-group wage inequality. Thirdly, the derivative of equation (11) with respect to $\theta^{u}$ equals $\frac{1}{\sigma}\left(\frac{\theta^{s}}{\theta^{u}}\right)^{\rho}-\frac{\underline{\beta}}{w_{\bar{\alpha}}^{n c}}$, which is increasing in $\theta^{u}$ if $\underline{\sigma}$ is small or if $\theta^{s} / \theta^{u}$ is large. Finally, if $\underline{\beta}=0$, equation (11) equals $\theta^{s^{\frac{\sigma-1}{\sigma}}} \theta^{u^{\frac{1}{\sigma}}}$. Now, the effect of an increase in $\theta^{s}$ is larger if $\sigma>2$ and $\underline{\beta}>0$ increases this effect.

After the least productive worker has adopted a computer, between-group wage inequality falls because $\frac{\partial w_{\bar{\alpha}} / \partial-V}{\bar{\alpha}}<\frac{\partial w_{\underline{B}} / \partial-V}{\underline{\beta}}$. Finally, if $V=0$, between-group wage inequality is back at is level prior to computerization.

INSERT FIGURE 4 OVER HERE

\section{Empirical Analysis}

\subsection{Data and Construction of Variables}

We use the March Demographic Supplements to the CPS from 1964 to 2001 for information about the standard labor market variables and to construct labor supply in the period 19632000. The October School Enrollment Supplements to the CPS from 1984, 1989, 1993, and 1997 are used for information about computer use at work. The Appendix provides a detailed overview of the construction of labor supply, annual wages, and computer use in the period 1963-2000 using these data.

Important data that is missing from the CPS is systematic information on computer use. Computer use is only available in four years $(1984,1989,1993$, and 1997) and has been imputed consistent with the break-even wage approach of the model, using the figures from 
the March and October CPS files (see Appendix A.4 and A.5 for more details). The imputed fractions of skilled and unskilled workers using computers are displayed in Figure 5. The pattern of diffusion shows a S-shaped diffusion pattern, which is consistent with other evidence on the diffusion of new technologies (e.g., David, 1969 for an overview). From Figure 5 it can be read that computer use for skilled workers has risen rather rapidly since the early 1970s and that computer use for unskilled workers started to increase around 1980.

While this imputation is far from ideal, it suggests that IT-related technological change has been going on since at least the early 1970s and has continued throughout later decades. This is consistent with several figures brought together by Card and DiNardo (2002, Section II.A) on the diffusion of IT at the workplace and Bresnahan's inference that a non-negligible fraction of U.S. workers were employed in firms with computer access from the early 1970s onwards (Bresnahan, 1999).

\section{INSERT FIGURE 5 OVER HERE}

\subsection{Econometric Specification of the Model}

To estimate between-group wage inequality we estimate the log of labor demand equation (2), allowing for a time trend. To do so, the supply and wages in terms of efficiency units of both types of labor have to be determined. This yields the following equation for estimating between-group wage inequality:

$$
\ln \left(\frac{\bar{w}_{s}}{\bar{w}_{u}}\right)=\ln \left(\gamma_{0} w^{e u}\left(\frac{\bar{w}_{u}+\left(\theta^{u}-1\right) w_{b e}^{u} \bar{C}_{u}}{\bar{w}_{u}}\right)+\gamma_{0}\left(\theta^{s}-1\right) w^{e u} \bar{C}-\left(\theta^{s}-1\right) \frac{w_{b e}}{\bar{w}_{u}} \bar{C}\right),
$$

where $w^{e u}=\left(\frac{U^{e}+U^{e}\left(\theta^{u}-1\right) F^{u}}{S^{e}+S^{e}\left(\theta^{s}-1\right) F^{s}}\right)^{1 / \sigma} e^{\gamma_{1} t}$ and $F^{u}$ and $F^{s}$ are the wage-bill shares of the computer users within both groups. This equation has been estimated by non-linear least squares with $\theta^{s}$, 
$\theta^{u}, \gamma_{0}$, and $\gamma_{1}$ as the unknown parameters. The derivation of the equations for estimation is given in Appendix A.6.

Note that if not all subgroups of skilled workers are equally substitutable with unskilled workers and vice versa, the estimate for between-group wage inequality will underestimate the productivity gains from computer use, because the productivity gains will not have affected the other group as would have been the case if we obtained the perfect division of the labor force into groups of skilled and unskilled workers. Since our division of skilled and unskilled workers into two groups manufacturing different goods might not be the best split of the sample, we expect the estimate to be relatively low compared to the withingroup estimate of the proportional productivity gain from computer use.

For within-group wage inequality the following two equations have been estimated:

$$
\ln \left(\frac{w_{90^{t h}}^{s}}{w_{10^{t h}}^{s}}\right)=\ln \left(\gamma_{0}+\gamma_{0}\left(\theta^{s}-1\right) C_{90^{t h}}^{s}-\left(\theta^{s}-1\right) \frac{w_{b e}}{w_{10^{t h}}^{s}} C_{90^{t h}}^{s}\right)
$$

for skilled workers, and

$$
\ln \left(\frac{w_{90^{t h}}^{u}}{w_{10^{t h}}^{u}}\right)=\ln \left(\gamma_{0}+\gamma_{0}\left(\theta^{u}-1\right) C_{90^{t h}}^{u}-\left(\theta^{u}-1\right) \frac{w_{b e}}{w_{10^{t h}}^{u}} C_{90^{t h}}^{u}\right)
$$

for unskilled workers. These equations have also been estimated by non-linear least squares with $\theta^{\mathrm{s}}, \theta^{\mathrm{u}}$, and $\gamma_{0}$ as the unknown parameters. Again, the derivation of these equations is shown in Appendix A.6.

Note that if there is heterogeneity in the quality of the computer equipment, the estimate for within-group wage inequality is likely overestimate the average productivity gains from computer use because it measures the productivity gains of the worker at the $90^{\text {th }}$ 
percentile relative to the worker at the $10^{\text {th }}$ percentile. If the allocation of computers is optimal, the most productive worker will get the best computer. In addition, all differences between workers within one group are addressed to differences in computer use. In all likelihood there might be other differences between these workers, which will now be included in the estimate for the proportional productivity gain from using a computer. Hence, we regard the estimate for the proportional productivity gain to be the close to the upper bound of the expected productivity gains from computer use.

\subsection{Estimation Results}

Table 3 reports the results from estimating equation (12). First we have ran a regression without taking into account the additional supply created by computer use and the proportional productivity gains from using a computer. The regression results are reported in the first column and comparable to the estimates reported by Katz and Murphy (1992) for the period 1963-1987. ${ }^{29}$ They obtain an estimate for $\sigma$ of 1.41 for a comparable but different definition of skilled and unskilled workers, compared to 1.82 here. The use of weighted series does not lead to a significantly different estimate (see Appendix A.3 for details about controlling for changes in the composition of the U.S. labor force). The annual increase in the demand for skilled labor is about 2.4 percent, which is somewhat lower than the 3.3 percent obtained by Katz and Murphy (1992). This model is consistent with the explanation that the increase in the skilled workers' wages is caused by a slowdown in the growth rate of the supply of skilled workers since the early 1980s. It should be noted that we are aware of the serial correlation in the data and we consider the estimates in this section as evidence

\footnotetext{
${ }^{29}$ It is also consistent with the estimates without the inclusion of capital of Krusell, Ohanian, Ríos-Rull and Violante (2000) for the period 1963-1992. See Acemoglu (2002, Table 2, p. 30).
} 
consistent with our model, reinforcing the argument and do not regard the estimates as clear evidence.

The second column reports estimates in which the proportional productivity gains are not allowed to differ from one another, i.e. $\theta^{s}=\theta^{u}$. In addition, the data used are not weighted for changes in the composition of the U.S. workforce. The estimated proportional productivity gain for $\theta^{s}=\theta^{u}$ equals 1.15 . These estimates suggest that the proportional productivity gain from computer use is substantial (15 percent) and lies between approximately 5 and 25 percent. This productivity gain can also be interpreted as the costs of the computer relative to the wage of the marginal worker who just adopted a computer (i.e., at the break-even point (equations (3)). This estimate seems reasonable and consistent with the figures about the costs of computer use relative to the wage shown in Section 3.

The elasticity of substitution from this regression equals 2.52 , which is substantially higher than the estimate from the Katz-Murphy model without the additional supply and productivity effects. This higher estimate for the elasticity of substitution is consistent with a larger fraction of skilled workers using the computer compared to unskilled workers. This effect leads to a relatively larger increase in the supply of skilled workers (in terms of efficiency units) than in the previous estimates (not including the additional supply), leading to a higher elasticity of substitution. The time trend for the annual increase in the demand for skilled labor has dropped from 2.4 percent to 1.4 percent. This fall can be interpreted as the model accounting for almost 42 percent of the unexplained increase in the demand for skilled workers. $^{30}$

\footnotetext{
${ }^{30}$ Note that this higher elasticity of substitution is also consistent with the acceleration hypothesis of Acemoglu (1998) because an elasticity of substitution larger than 2 requires in the Katz-Murphy model a significant acceleration in skill-biased technological change to explain the data. However, our model accounts for a higher elasticity of substitution by a relatively larger supply in terms of efficiency units of skilled workers.
} 
The third column of Table 3 reports estimates allowing for differences in the productivity gain between skilled and unskilled workers. The point estimate is about 19 percentage points higher for skilled workers compared to unskilled workers: $\theta^{s}=1.27$ and $\theta^{u}=$ 1.08. This estimate for skilled workers is substantially higher than the 15 percent productivity increase found when $\theta^{s}=\theta^{u}$. These estimates seem to suggest that skilled workers gain more in terms of productivity than unskilled workers. However, the margins are rather large and it is not possible to statistically discriminate between the coefficients for skilled and unskilled workers. The elasticity of substitution turns out to be relatively high (4.30), but given the substantial margins, its precise magnitude is not particularly clear from this regression. The time trend has dropped further to .01 . Hence, the model explains more than 60 percent of the unexplained increase in the demand for skilled workers.

Note that our results are more convincing than the estimates of Krusell, Ohanian, RíosRull and Violante (2000). Their evidence on falling capital equipment prices running wage inequality is not the variable providing the explanatory power in their model. It turns out that it is basically the relative supply of skilled workers that runs the results, consistent with the Katz-Murphy model. Acemoglu (2002) re-estimates the Krusell-Ohanian-Ríos-Rull-Violante model and finds that the level or the $\log$ of the relative price of equipment capital is insignificant and that the measure performs worse than a linear time trend. In our results, the additional terms for the proportional productivity gains and additional supply are significant and do not lead to a lower explanatory power of the model. In addition, we are able to explain a substantial part of the Katz-Murphy time trend. ${ }^{31}$

\section{INSERT TABLE 3 OVER HERE}

\footnotetext{
${ }^{31}$ See Acemoglu (2002) for a more detailed discussion of estimating the Krusell-Ohanian-Ríos-Rull-Violante model.
} 
Table 4 reports the results of estimating equations (13) for within-group wage inequality. The estimation is based on an analysis of the $90^{\text {th }}-10^{\text {th }}$ percentile of both wage distributions and uses the non-weighted data. The regression equation is set in such a way that for computer use below 10 percent, within-group wage inequality considered to be constant. The first column of Table 4 reports an estimate for the proportional productivity gain of using a computer for skilled workers of $\theta^{s}=1.41$ with margins between 1.35 and 1.47 . This estimate suggests a productivity gain of around 40 percent from using a computer. The regression results reported in the second column of Table 4 suggest a similar proportional productivity gain for unskilled workers, although the confidence interval is somewhat wider: $\theta^{u}=1.41$ $(1.32,1.51)$. These estimates are higher than can be expected from the 21 percent obtained from the back-of-the-envelope calculation presented in Section 3; also relative to the estimates for between-group wage inequality these estimates are relatively high. ${ }^{32}$ On the other hand, estimates reported by Bresnahan, Brynjolfsson and Hitt (2002, Table 8, p. 365) are consistent with such a high estimate for the proportional productivity gain from adopting computers. They argue that there are large adjustments costs to the successful use of computers, which are not only due to the installation of computers itself but also to the change in organization structure, technical assistance and other co-inventions going along with computerization. In addition, an alternative way to interpret these estimates relative to the between-group estimates is to consider different vintages of computers. This would lead to productivity gains of the latest vintage, compared to not using a computer, to be equal to approximately 40 percent of the wage.

To investigate whether these estimates are sensitive to the measure of within-group

\footnotetext{
${ }^{32}$ Weighing the data to control for compositional changes during 1963-2000 gives estimates of $\theta^{s}=1.29$ and $\theta^{u}$ $=1.47$.
} 
wage inequality, two different definitions also have been tested. First, the $80^{\text {th }}-20^{\text {th }}$ percentile of the wage distribution has been used as a measure of wage inequality. Now, $\theta^{s}=1.21$ and $\theta^{u}$ $=1.28$. Secondly, the $70^{\text {th }}-30^{\text {th }}$ percentile of both wage distributions have been investigated. Here, $\theta^{s}=1.15$ and $\theta^{u}=1.12$. These estimates suggest that the proportional productivity gains are lower if within-group wage inequality is allowed to fluctuate after 20 and 30 percent of the workers within each group have adopted computers.

\section{INSERT TABLE 4 OVER HERE}

As argued above, the interpretation of the different estimates for the proportional productivity gains in Tables 3 and 4 can be viewed upon as lower and upper bound productivity gains. The relatively low estimate for the productivity gain reported in Table 3 suggests that the additional supply plays an important role and stresses the importance of analyzing this supply effect separately from the productivity effect. The relatively high estimates for the productivity gain reported in Table 4 are probably due to by addressing all within-group differences to computerization. When using a more moderate definition of within-group wage inequality, the coefficients become lower, suggesting lower productivity gains more in line with the estimates of between-group wage inequality.

\section{Concluding Remarks}

When considering the allocation of computers among groups of workers, it becomes apparent that those workers who have adopted computers gain from the increased productivity of using computers. Within the same group, workers who have not adopted computers suffer from an increased supply of efficiency units of labor. Hence, it is important to distinguish between individual and group effects of computer adoption to understand the wage dynamics of computer diffusion. Our model indeed shows that it is important to explicitly consider who 
adopts a computer at what point in time to help understand the effects of computers on the wage structure. In this way, we are able to explain why the effects of computer adoption are different in the 1970s than in the 1980s (Autor, Katz and Krueger, 1998), why computer use was already high in the early 1980s without affecting relative wages (Bresnahan, 1999), and why in the 1990s wage inequality between skilled and unskilled seems to be leveling off (Card and DiNardo, 2002).

There are two main directions for future research. First, our model shows the importance of the distinction between individual and group effects (in the sense that groups of workers produce a similar product) when considering computer adoption. It is therefore very important to distinguish the right groups. An avenue of further investigation would be to look more carefully into which groups of workers substitute each other and which groups do not. Secondly, the model is able to reflect the pattern and timing of wage inequality in the United States. This is particularly so because of the relatively large initial (i.e., before computers became around) wage inequality between skilled and unskilled workers, and the limited way in which skilled and unskilled workers can be substituted. It would be interesting to analyze countries in which initial wage inequality would be relatively low and skilled and unskilled workers are better substitutable. Countries of interest here are continental European countries, such as France and Germany.

\section{Appendix}

\section{A.1. Labor Supply}

Labor supply is computed for skilled and unskilled workers. Skilled workers are defined as workers with at least a completed college education and unskilled workers as workers with educational levels below a completed college education. We only use workers who reported to 
be employed in the previous year. Full-time workers are weighted with a factor 1, and parttime workers with the number of hours worked in the preceding week divided by 40 (the average number of hours worked by the full-time workers). Since the exact number of weeks worked is not known for several years in the data, full-year workers are weighted with a factor 1 and part-year workers with a factor .5 .

Figure A.1 shows the share of skilled workers resulting from this exercise. The figure shows that the share of skilled workers is steadily increasing from about 15 percent in 1963 to 36 percent in 2000 . The slope is steepest in the 1960 s and 1970 s, which is consistent with the figures recently presented by Card and Lemieux (2001) for the relative supply of collegeeducated workers by different age groups.

\section{INSERT FIGURE A.1 OVER HERE}

\section{A.2. Wages}

Changes in the U.S. wage structure in the period 1963-2000 are illustrated using data on the annual earnings of full-time, full-year, wage and salary workers from the March Current Population Surveys of 1964 to 2001 (covering the earnings in the period from 1963 to 2000). Full-time, full-year, wage and salary workers are those working at least 35 hours per week and working at least 40 weeks in the previous calendar year. We only use annual wages between $\$ 1,000$ and $\$ 900,000$.

We use annual earnings for three reasons. The first reason is that computer use is only available on a yearly basis from the October 1984, 1989, 1993, and 1997 School Enrollment Supplements to the CPS (see A.4 for more details), which only allows for a computation of break-even wages by year. So, a worker makes an annual decision to adopt a computer for that year. The second reason is that information on weeks worked and usual weekly hours in the 
previous calendar year is available in the March CPS from 1976 onwards. The 1963-1975 period is only covered by bracketed weeks worked information and hours worked last week. This makes it harder to measure weekly or hourly earnings. ${ }^{33}$ The third reason is that computers can be shared among part-time workers, which induces computer use at lower wage levels as well. While this can be accounted for, the limited information about hours worked, is likely to bias our estimates.

To avoid measurement problems, part-time and part-year workers are not included when constructing the wage variable. Only full-time, full-year wages and salaries are used, which provides information on the gross annual wages. Since the dispersion in productivity parameters, reflected by wage differentials within the groups of skilled and unskilled workers, is essential to the model, no correction has been made for demographic factors. To compute real wages we apply the price deflator for personal consumption expenditures from the NIPA. ${ }^{34}$ In terms of the model, wage differentials between skilled and unskilled workers are of interest but within-group wage differentials are also important. The average wages for workers with productivity $\bar{\alpha}$ are defined as the $90^{\text {th }}$ percentile of the wage distribution of skilled workers and the average wages for workers with productivity $\underline{\alpha}$ as the $10^{\text {th }}$ percentile of this wage distribution. Similarly, the average wages for workers with productivity $\bar{\beta}$ are defined as the $90^{\text {th }}$ percentile of the unskilled workers' wage distribution and the average wages for workers with productivity $\underline{\beta}$ as the $10^{\text {th }}$ percentile of the unskilled workers' wage distribution. ${ }^{35}$

\footnotetext{
${ }^{33}$ Katz and Murphy (1992), Juhn, Murphy and Pierce (1993) and Autor, Katz and Krueger (1998) discuss several ways in which hours worked can be imputed for the period 1963-1975.

${ }^{34}$ The data are taken from the Annual Revision of the NIPA made available by the Bureau of Economic Analysis. Katz and Murphy (1992) have used the same deflator.

${ }^{35}$ In the regression analysis we also test whether the results are sensitive to using the $80^{\mathrm{h}}, 70^{\mathrm{h}}, 20^{\mathrm{h}}$ and $30^{\mathrm{h}}$ percentiles of both wage distributions.
} 


\section{A.3. Changes in the Composition of the U.S. Labor Force}

Since the composition of the U.S. labor force changed in the period 1963-2000, an alternative measure of the wage development has also been used. This alternative measure has been constructed by defining 32 cells for four age groups, four educational groups and controlling for gender. These 32 cells have been weighted such that their sizes are equal to the size in 2000. Based on these weights, average and percentile wages have been determined. The age groups are $<29,30-39,40-49$ and $>50$, the educational groups are less than highschool, highschool degree, more than highschool but less than a college degree, and a college degree or more. Thus, the composition of the workforce and labor supply within the group of skilled and unskilled workers is equal in all years. The use of more than 32 cells does not significantly change the regression results, but leads in some instances to rather low numbers of workers in each cell. The use of less than 32 cells also gives comparable results.

\section{A.4. Computer Use}

Individual computer use has been calculated from the October 1984, 1989, 1993, and 1997 School Enrollment Supplements to the CPS as the fraction of currently employed full-time, year-round workers who answered yes to the question, "Do you use a computer directly at work?". The survey defines a computer as a desktop terminal or PC with keyboard and monitor and does not include an electronic cash register or a hand-held data device. 60,396, $58,401,59,710$, and 52,753 observations were used to calculate these frequencies in 1984 , 1989, 1993, and 1997, respectively. We have used full-time, year-round workers only to compute computer use at work because these workers have also been used to calculate wages and labor supply (see A.1 and A.2 above). The fractions of skilled workers using computers were 45.2 percent (1984), 62.8 percent (1989), 70.4 percent (1993), and 76.6 percent (1997). 
The fractions of unskilled workers using computers at work in the same years were 21.6, 33.1, 37.6 and 42.8 percent, respectively. For the sample as a whole, computer use was $28.1,41.5$, 49.4 and 56.1 percent in 1984, 1989, 1993, and 1997, respectively.

\section{A.5. Imputing Computer Use}

We used the four years from the October 1984, 1989, 1993, and 1997 School Enrollment Supplements to the CPS from which computer use was available to impute computer use in the other years in the period 1963-2000, using wages from the March CPS.

Consistent with the theory presented in the paper, if computer use equals $x$, the worker at $(100-x)^{\text {th }}$ percentile of the wage distribution is the one who just adopted a computer. In other words, the wage at the $(100-x)^{\text {th }}$ percentile of the wage distribution is defined as the break-even wage for a particular group of workers in a particular year. For example, in 1989 computer use among skilled (unskilled) workers equaled 62.8 (33.1) percent implying that the break-even wage for skilled workers to adopt a computer is equal to the wage at the $37.2^{\text {th }}$ $\left(66.9^{\text {th }}\right)$ percentile of the skilled (unskilled) workers' wage distribution. This information is available for 1984, 1989, 1993, and 1997. The break-even wages in 1992 dollars for skilled workers are $\$ 30,961, \$ 25,956, \$ 24,289$, and $\$ 20,644$, and for unskilled workers $\$ 28,606$, $\$ 24,112, \$ 23,317$, and $\$ 20,644$, for $1984,1989,1993$, and 1997 , respectively.

Using these break-even wages, we can impute computer use and the break-even wage for each year between 1963 and 2000 by estimating the equation $\ln w=C+\alpha Y+\varepsilon$, using the four years for which information is available. In this estimation $\ln w$ is the $\log$ of the real annual break-even wage, $C$ is a constant, $Y$ are years dummies, and $\varepsilon$ is an error term with the usual assumptions. For skilled workers this yields the following equation (standard errors in brackets) for the break-even wage $\ln w=8.197(.187)-0.029(.002) Y$ and for unskilled 
workers it equals $\ln w=7.539(.229)-.023(.003) Y$. To generate computer use, all workers with wages in year $Y$ above the break-even wage are assumed to use a computer at work. Figure 5 plots this imputed computer use for the period 1963-2000.

\section{A.6. Econometric Specification}

We made assumptions about the distribution of productivity parameters to generate an analytical solution. To estimate the model, we use the actual distribution of productivity parameters.

\section{A.6.1. Between-Group Wage Inequality}

In accordance with labor demand equation (2), and allowing for a time trend $\left(e^{\gamma_{1} t}\right)$ in wages, the relative wage in efficiency units equals

$$
w^{e u}=\left(\frac{\psi U}{\chi S}\right)^{1 / \sigma} e^{\gamma_{1} t}
$$

\section{Supply of Workers}

Empirically, the supply of skilled labor $S$ in efficiency units equals $S=S^{e}+S^{e}\left(\theta^{s}-1\right) F^{s}$, where $F^{s}$ denotes the share of efficiency units of skilled workers using a computer. This share equals

$$
F^{s}=\left(\int_{c} a_{i} p^{s} \mathrm{~d} a_{i}\right) /\left(\int_{c} a_{i} p^{s} \mathrm{~d} a_{i}+\int_{n} a_{i} p^{s} \mathrm{~d} a_{i}\right)
$$

where $c$ are computer users and $n$ non-users.

$a_{i}$ cannot observed directly, but is derived from the information about wages according to $\quad a_{i}=\frac{w_{i}+\left(\theta_{s}-1\right) w_{b e}^{s}}{\theta_{s}}$. In principle, this expression has to be substituted into equation (A.2). 
However, analysis of the data shows that for reasonable values of $\theta^{\mathrm{s}}, F^{s}$ is almost constant in $\theta^{\mathrm{s}}$. To avoid estimation problems, $F^{s}$ is approximated by

$$
F^{s}=\frac{\int_{c} w_{i} p^{s} \mathrm{~d} a_{i}}{\int_{c} w_{i} p^{s} \mathrm{~d} a_{i}+\int_{n} w_{i} p^{s} \mathrm{~d} a_{i}},
$$

which can be understood as the wage-bill share of skilled computer users in the total skilled workers' wage-bill.

For unskilled workers, $F^{u}$ is approximated in a similar way. The supply of unskilled workers in efficiency units equals $U=U^{e}+U^{e}\left(\theta^{u}-1\right) F^{u}$, where $F^{u}$ is the share of unskilled workers using a computer:

$$
F^{u}=\frac{\int_{c} w_{i} p^{u} \mathrm{~d} b_{i}}{\int_{c} w_{i} p^{u} \mathrm{~d} b_{i}+\int_{n} w_{i} p^{u} \mathrm{~d} b_{i}},
$$

\section{Efficiency Units of Labor}

Wages in terms of efficiency units are not directly observed. We therefore have estimated the wage ratio of skilled and unskilled workers, the $90^{\text {th }}-10^{\text {th }}$ percentile wage differential for skilled workers, and the $90^{\text {th }}-10^{\text {th }}$ percentile wage differential for unskilled workers. The wage of a skilled worker $i$ equals

$$
w_{i}=\gamma_{0} w_{s}^{e u}+\gamma_{0}\left(\theta^{s}-1\right) w_{s}^{e u} C_{i}^{s}-V C_{i}^{s},
$$

where $C_{i}^{s}=1$ if worker $i$ uses a computer and 0 otherwise. Since $V=\left(\theta^{s}-1\right) w_{b e}$, averaging over all skilled workers leads to

$$
\bar{w}_{s}=\gamma_{0} w_{s}^{e u}+\gamma_{0}\left(\theta^{s}-1\right) w_{s}^{e u} \bar{C}-\left(\theta^{s}-1\right) w_{b e} \bar{C}
$$

where a bar over a variable indicates an average term. Dividing by $\bar{w}_{u}$, rearranging terms and taking $\log$ s then yields 
(A.4) $\ln \left(\frac{\bar{w}_{s}}{\bar{w}_{u}}\right)=\ln \left(\gamma_{0} w^{e u}\left(\frac{\bar{w}_{u}+\left(\theta^{u}-1\right) w_{b e}^{u} \bar{C}_{u}}{\bar{w}_{u}}\right)+\gamma_{0}\left(\theta^{s}-1\right) w^{e u} \bar{C}-\left(\theta^{s}-1\right) \frac{w_{b e}}{\bar{w}_{u}} \bar{C}\right)$.

Substituting equation (A.1) for $w^{e u}$, this equation can be estimated by non-linear least squares with $\theta^{\mathrm{s}}, \theta^{\mathrm{u}}, \gamma_{0}$, and $\gamma_{1}$ as the unknown parameters.

\section{A.6.2. Within-Group Wage Inequality}

Taking into consideration the above derivation for between-group wage inequality, the $90^{\text {th }}-10^{\text {th }}$ percentile wage differential within the group of skilled workers can be written as

$$
w_{90^{t h}}^{s}=\gamma_{0} w_{s}^{e u}+\gamma_{0}\left(\theta_{s}-1\right) w_{s}^{e u} C_{90^{t h}}^{s}-V C_{90^{t h}}^{s}
$$

where $C_{90^{t h}}^{s}$ indicates the years in which the $90^{\text {th }}$ percentile of the wage distribution of skilled workers have adopted a computer. According to the imputed computer use data in Figure 5, this is in 1974. Dividing this expression by $w_{10^{t h}}^{s}$ yields the equation for estimating within-group wage inequality of skilled workers

$$
\ln \left(\frac{w_{90^{t h}}^{s}}{w_{10^{t h}}^{s}}\right)=\ln \left(\gamma_{0}+\gamma_{0}\left(\theta^{s}-1\right) C_{90^{t h}}^{s}-\left(\theta^{s}-1\right) \frac{w_{b e}}{w_{10^{t h}}^{s}} C_{90^{t h}}^{s}\right)
$$

which has to be estimated by non-linear least squares as well.

Similarly, the regression equation for the within-group wage inequality of unskilled workers equals

$$
\ln \left(\frac{w_{90^{t h}}^{u}}{w_{10^{t h}}^{u}}\right)=\ln \left(\gamma_{0}+\gamma_{0}\left(\theta^{u}-1\right) C_{90^{t h}}^{u}-\left(\theta^{u}-1\right) \frac{w_{b e}}{w_{10^{t h}}^{u}} C_{90^{t h}}^{u}\right)
$$

which is also estimated by non-linear least squares. 


\section{References}

Acemoglu, Daron (1998), "Why Do New Technologies Complement Skills? Directed Technical Change and Wage Inequality," Quarterly Journal of Economics, vol. 113, no. 4, pp. 1055-1089.

Acemoglu, Daron (2002), "Technical Change, Inequality, and the Labor Market," Journal of Economic Literature, vol. 40, no.1, pp. 7-72.

Aghion, Philippe (2002), "Schumpeterian Growth Theory and the Dynamics of Income Inequality," Econometrica, vol. 70, no. 3, pp. 855-882.

Aghion, Philippe, Peter Howitt and Giovanni L. Violante (2002), "General Purpose Technology and Wage Inequality," Journal of Economic Growth, vo. 7, no. 4, pp. 315345.

Angrist, Joshua A. (1995), "The Economic Returns to Schooling in the West Bank and Gaza Strip," American Economic Review, vol. 85, no. 5, pp. 1065-1087.

Allen, Steven G. (2001), "Technology and the Wage Structure," Journal of Labor Economics, vol. 19 , no. 2, pp. 440-483.

Autor, David H., Lawrence F. Katz and Alan B. Krueger (1998), "Computing Inequality: Have Computers Changed the Labor Market?," Quarterly Journal of Economics, vol. 113, no. 4, pp. 1169-1213.

Autor, David H., Frank Levy and Richard J. Murnane (2002), "Upstairs, Downstairs: Computers and Skills on Two Floors of a Large Bank," Industrial and Labor Relations Review, vol. 55, no. 3, pp. 432-447.

Berman, Eli, John Bound and Zvi Griliches (1994), "Changes in the Demand for Skilled Labor within U.S. Manufacturing Industries," Quarterly Journal of Economics, vol. 109, no. 1, pp. 367-398.

Berndt, Ernst R. and Catherine Morrison (1995), "High-Tech Capital Formation and Economic Performance in U.S. Manufacturing Industries: An Explorative Analysis," Journal of Econometrics, vol. 65, no. 1, pp. 9-43.

Bresnahan, Timothy F., Erik Brynjolfsson and Lorin Hitt (2002), "Information Technology, Workplace Organization, and the Demand for Skilled Labor: Firm-Level Evidence," Quarterly Journal of Economics, vol. 117, no. 1, pp. 339-376.

Bresnahan, Timothy F. and Manuel Trajtenberg (1995), "General Purpose Technologies: "Engines of Growth"?," Journal of Econometrics, vol. 65, no. 1, pp. 83-108.

Card, David and John E. DiNardo (2002), "Skill-Biased Technological Change and Rising Wage Inequality: Some Problems and Puzzles," Journal of Labor Economics, vol. 20, no. 4 , pp. 733-83.

Card, David and Thomas Lemieux (2001), "Can Falling Supply Explain the Rising Return to College for Younger Men? A Cohort-Based Analysis," Quarterly Journal of Economics, vol. 116, no. 2, pp. 705-746.

Caroli, Eve and Cecilia García-Peñalosa (2002), "Risk Aversion and Rising Wage Inequality," Economics Letters, vol. 77, no. 1, pp. 21-26.

Caselli, Francesco (1999), "Technological Revolutions," American Economic Review, vol. 89, no. 1 , pp. 78-102.

Chari, V.V. and Hugo Hopenhayen (1991), "Vintage Human Capital, Growth, and the Diffusion of New Technology," Journal of Political Economy, vol. 99, no. 6, p. 11421165.

Chennells, Lucy and John Van Reenen (1997), "Technical Change and Earnings in British 
Establishments," Economica, vol. 64, no. 3, pp. 587-604.

David, Paul A. (1969), "A Contribution to the Theory of Diffusion," Research Center in Economic Growth Memorandum no. 71, Stanford University, June.

David, Paul A. and Trond E. Olsen (1986), "Equilibrium Dynamics of Diffusion when Incremental Technological Innovations Are Foreseen," Richerche Economiche, vol. 40, no. 3, pp. 738-770.

Davies, Stephen (1979), The Diffusion of Process Innovations (Cambridge: Cambridge University Press).

Doms, Mark, Timothy Dunne and Kenneth R. Troske (1997), "Workers, Wages and Technology," Quarterly Journal of Economics, vol. 112, no. 1, pp. 253-290.

Entorf, Horst, Michel Gollac and Francis Kramarz (1999), "New Technologies, Wages, and Worker Selection," Journal of Labor Economics, vol. 17, no. 3, pp. 464-491.

Entorf, Horst and Francis Kramarz (1997), "Does Unmeasured Ability Explain the Higher Wages of New Technology Workers?," European Economic Review, vol. 41, no. 6, pp. 1489-1509.

Galor, Oded and Omer Moav (2000), "Ability-Biased Technological Transition, Wage Inequality, and Economic Growth," Quarterly Journal of Economics, vol. 115, no. 2, pp. 469-497.

Galor, Oded and Daniel Tsiddon (1997), "Technological Progress, Mobility, and Economic Growth," American Economic Review, vol. 87, no. 3, pp. 363-382.

Geroski, Paul A. (2000), "Models of Technology Diffusion," Research Policy, vol. 29, no. 3, pp. 603-625.

Gorman, John A, John C. Musgrave, Gerald Silverstein and Kathy Comins (1985), "Fixed Private Capital in the United States," Survey of Current Business, vol. 65, no. 1, pp. 36-55.

Gould, Eric D., Omer Moav and Bruce A. Weinberg (2001), "Precautionary Demand for Education, Inequality, and Technological Progress," Journal of Economic Growth, vol. 6, no. 4, pp. 285-315.

Greenwood, Jeremy and Mehmet Yorukoglu (1997), “1974,” Carnegie Rochester Conference Series on Public Policy, vol. 46, pp. 49-95.

Griliches, Zvi (1957), "Hybrid Corn: An Exploration in the Economics of Technological Change," Econometrica, vol. 25, no. 4, pp. 501-522.

Griliches, Zvi (1958), "Research Costs and Social Returns: Hybrid Corn and Related Innovations," Journal of Political Economy, vol. 66, no. 5, pp. 419-431.

Hamermesh, Daniel (1993), Labor Demand (Princeton NJ: Princeton University Press).

Heckman, James J., Lance Lochner and Christopher Taber (1998), "Explaining Rising Wage Inequality: Explorations with a Dynamic General Equilibrium Model of Labor Earning with Heterogenous Agents," Review of Economic Dynamics, vol. 1, no. 1, pp. 1-58.

Helpman, Elhanan and Manuel Trajtenberg (1998), "Diffusion of General Purpose Technologies," in General Purpose Technologies and Economic Growth, Elhanan Helpman, ed. (Cambridge MA: MIT Press), pp. 85-119.

Johnson, George E. (1997), "Changes in Earnings Inequality: The Role of Demand Shifts," Journal of Economic Perspectives, vol. 11, no. 1, pp. 41-54.

Jorgenson, Dale W. (2001), "Information Technology and the U.S. Economy," American Economic Review, vol. 91, no. 1, pp. 1-32.

Jorgenson, Dale W. and Kevin J. Stiroh (1999), "Information Technology and Growth," American Economic Review, vol. 89, no. 2, Papers and Proceedings, pp. 109-115. 
Karshenas, Massoud and Paul L. Stoneman (1993), "Rank, Stock, Order, and Epidemic Effects in the Diffusion of New Process Technologies: An Empirical Model," Rand Journal of Economics, vol. 24, no. 4, pp. 503-528.

Katz, Lawrence F. (2000), "Technological Change, Computerization, and the Wage Structure," in Understanding the Digital Economy; Data, Tools, and Research, Erik Brynjolfsson and Brian Kahin, eds. (MIT Press, Cambridge MA), pp. 217-244.

Katz, Lawrence F. and David H. Autor (1999), "Changes in the Wage Structure and Earnings Inequality," in Handbook of Labor Economics, vol. 3, Orley Ashenfelter and David H. Card, eds. (North-Holland: Amsterdam), pp. 1463-1555.

Katz, Lawrence F. and Kevin M. Murphy (1992), "Changes in Relative Wages: Supply and Demand Factors," Quarterly Journal of Economics, vol. 107, no. 1, pp. 35-78.

Kiley, Michael T. (1999), "The Supply of Skilled Labour and Skill-Biased Technological Progress," Economic Journal, vol. 109, no, 5, pp. 708-724.

Krueger, Alan B. (1993), "How Computers Have Changed the Wage Structure: Evidence from Microdata, 1984-1989," Quarterly Journal of Economics, vol. 108, no. 1, pp. 3360.

Krusell, Per, Lee Ohanian, Víctor Ríos-Rull and Giovanni L. Violante (2000), “Capital-Skill Complementarity and Inequality: A Macroeconomic Analysis,” Econometrica, vol. 68, no. 5, pp. 1029-1053.

Levy, Frank and Richard J. Murnane (1996), "With What Skills Are Computers Complements?," American Economic Review, vol. 86, no. 2, Papers and Proceedings, pp. 258-262.

Mansfield, Edwin (1961), "Technical Change and the Rate of Imitation," Econometrica, vol. 29, no. 4, pp. 741-766.

Mansfield, Edwin (1965), "Rates of Return from Industrial R\&D," American Economic Review, vol. 55, no. 2, Papers and Proceedings, pp. 310-322.

Murphy, Kevin M., W. Craig Riddell and Paul M. Romer (1998), "Wages, Skills, and Technology in the United States and Canada," in General Purpose Technologies and Economic Growth, Elhanan Helpman, ed. (Cambridge MA: MIT Press:), pp. 283-309.

Stoneman, Paul L. (1976), Technological Diffusion and the Computer Revolution (Oxford: Oxford University Press).

Stoneman, Paul L. and Myung-Joong Kwon (1996), "Technology Adoption and Firm Profitability," Economic Journal, vol. 106, no. 5, pp. 952-962.

Violante, Giovanni L. (2002), "Technological Acceleration, Skill Transferability and the Rise in Residual Inequality," Quarterly Journal of Economics, vol. 117, no. 1, pp. 297-338.

Weinberg, Bruce A. (2001), "Experience and Technology Adoption," Unpublished Paper, Ohio State University, April. 
Figure 1

Wage Inequality in the United States

Panel A: $\ln \left(90^{\text {th }}\right.$ Percentile Skilled $)-\ln \left(10^{\text {th }}\right.$ Percentile Unskilled $)$

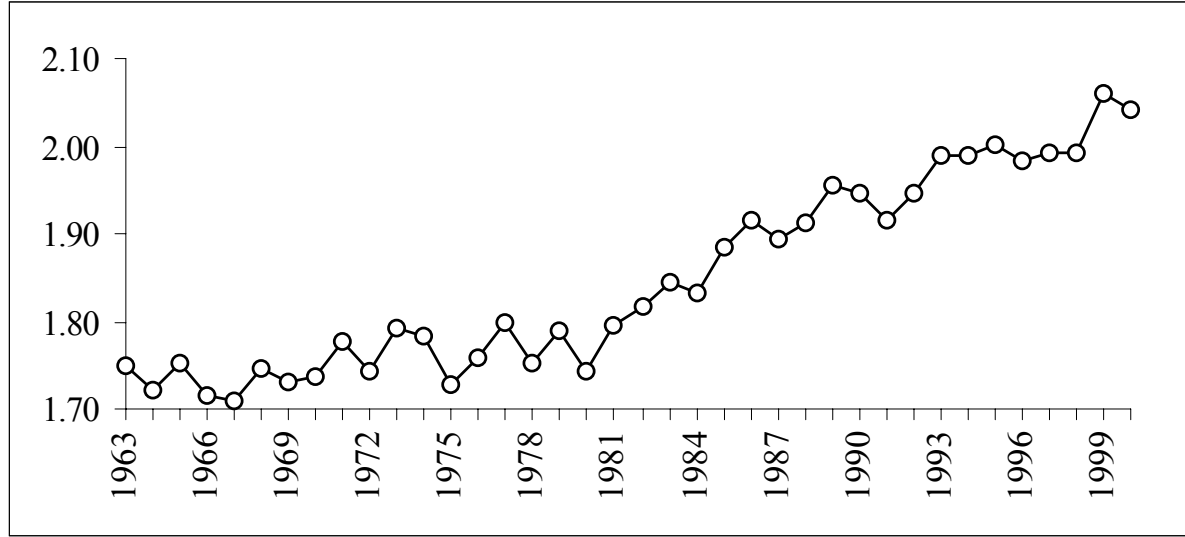

Panel B: $\ln \left(10^{\text {th }}\right.$ Percentile Skilled $)-\ln \left(10^{\text {th }}\right.$ Percentile Unskilled $)$

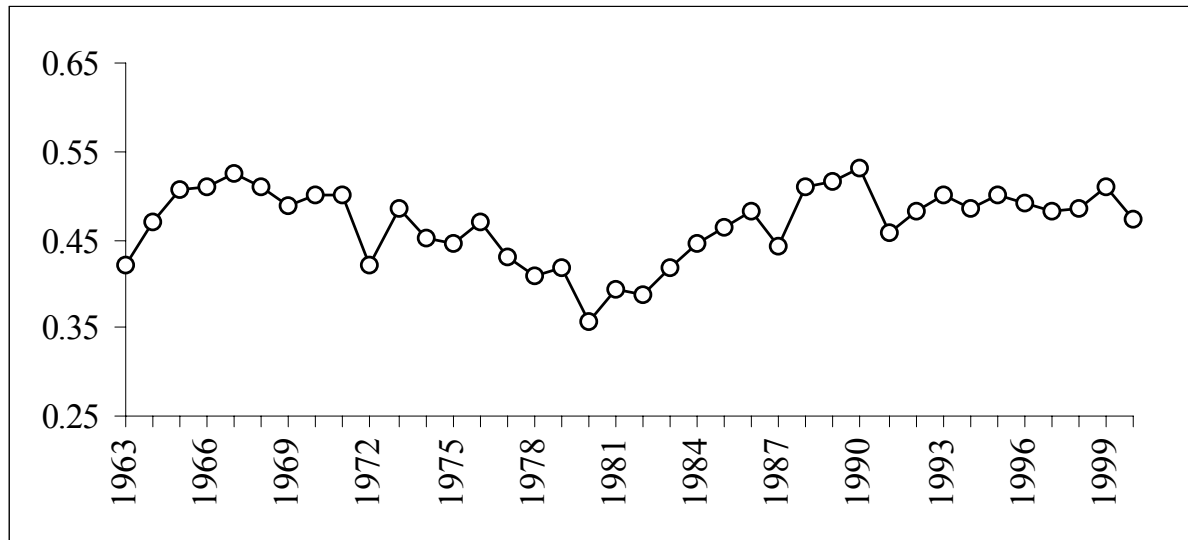

Panel C: $\ln \left(90^{\text {th }}\right.$ Percentile Unskilled $)-\ln \left(10^{\text {th }}\right.$ Percentile Unskilled $)$

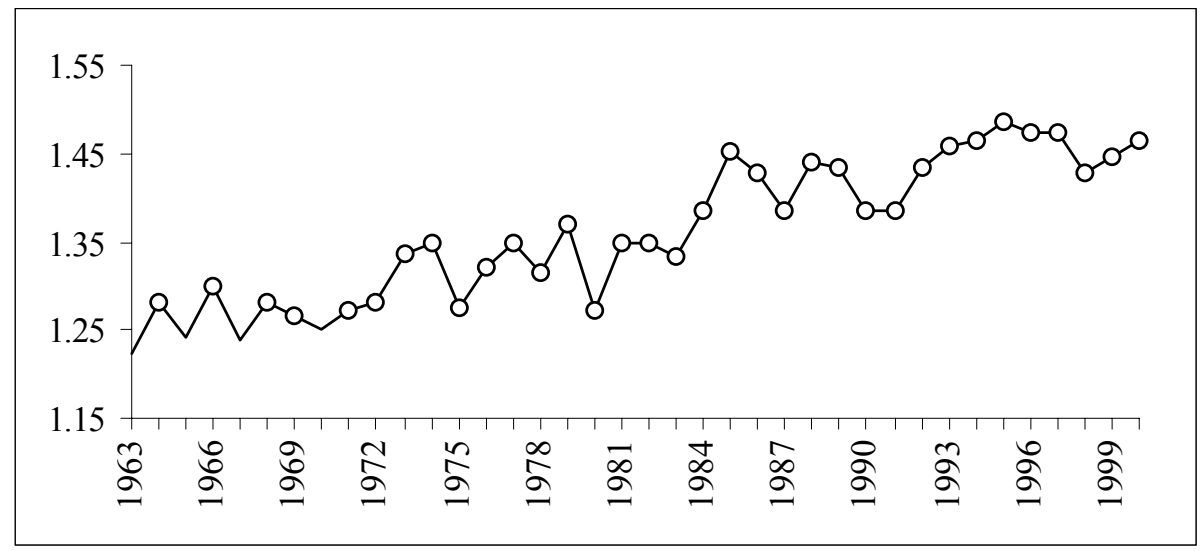

Note: Data are taken from the March CPS. Skilled workers are college graduates and higher; unskilled workers are the remaining ones. See the Appendix for further details about the data. 
Figure 2

Log Wage Differentials for Workers in Different Groups Earning the Same Wages in 1963

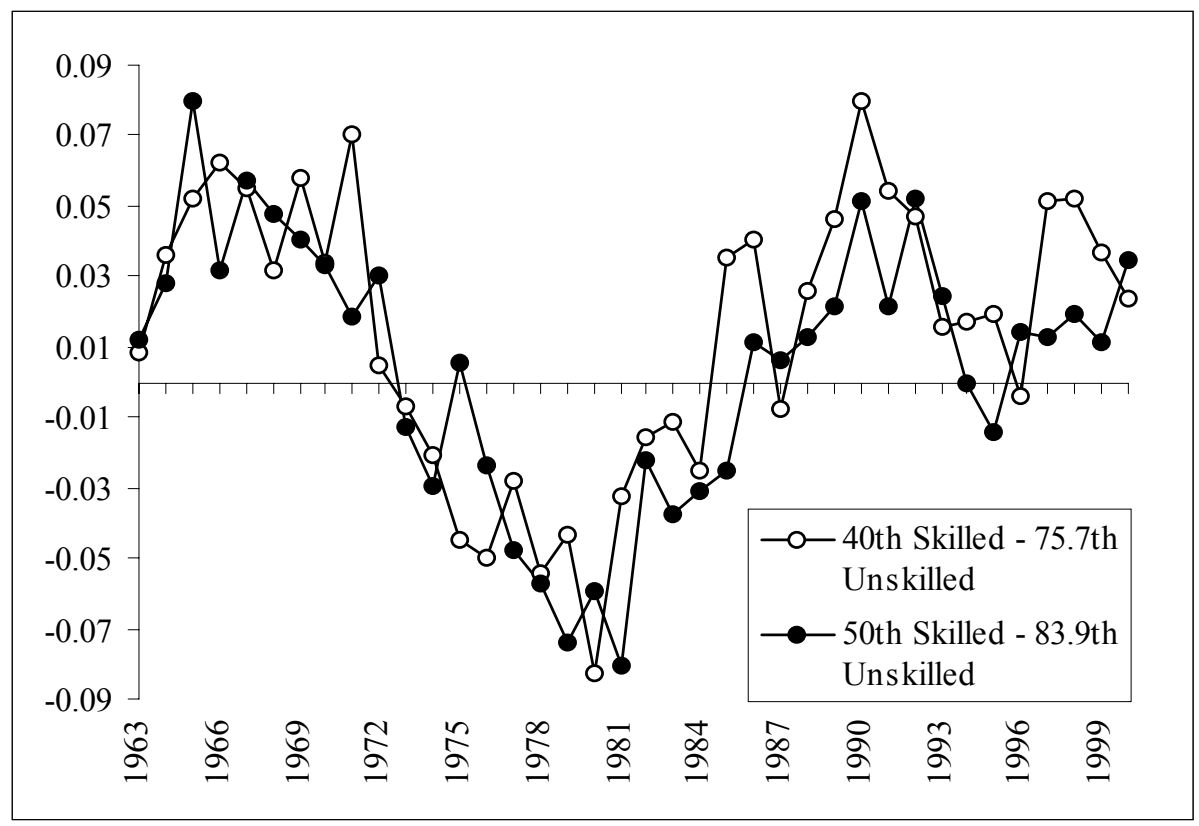

Note: Data are taken from the March CPS. Skilled workers are college graduates and higher; unskilled workers are the remaining ones. The comparison of wages is such that the wage of the skilled workers at the $40^{\text {th }}$ and $50^{\text {th }}$ percentile of the skilled wage distribution corresponds to the wages of the $75.7^{\text {th }}$ and $83.9^{\text {th }}$ percentile of the unskilled wage distribution in 1963 . Because the wages do no perfectly match in 1963, the actual ratio, in logarithmic terms, is not zero in 1963 but a small deviation can be observed from the figure. See the Appendix for further details about the data. 
Figure 3

Within-Group Wage Inequality over Time

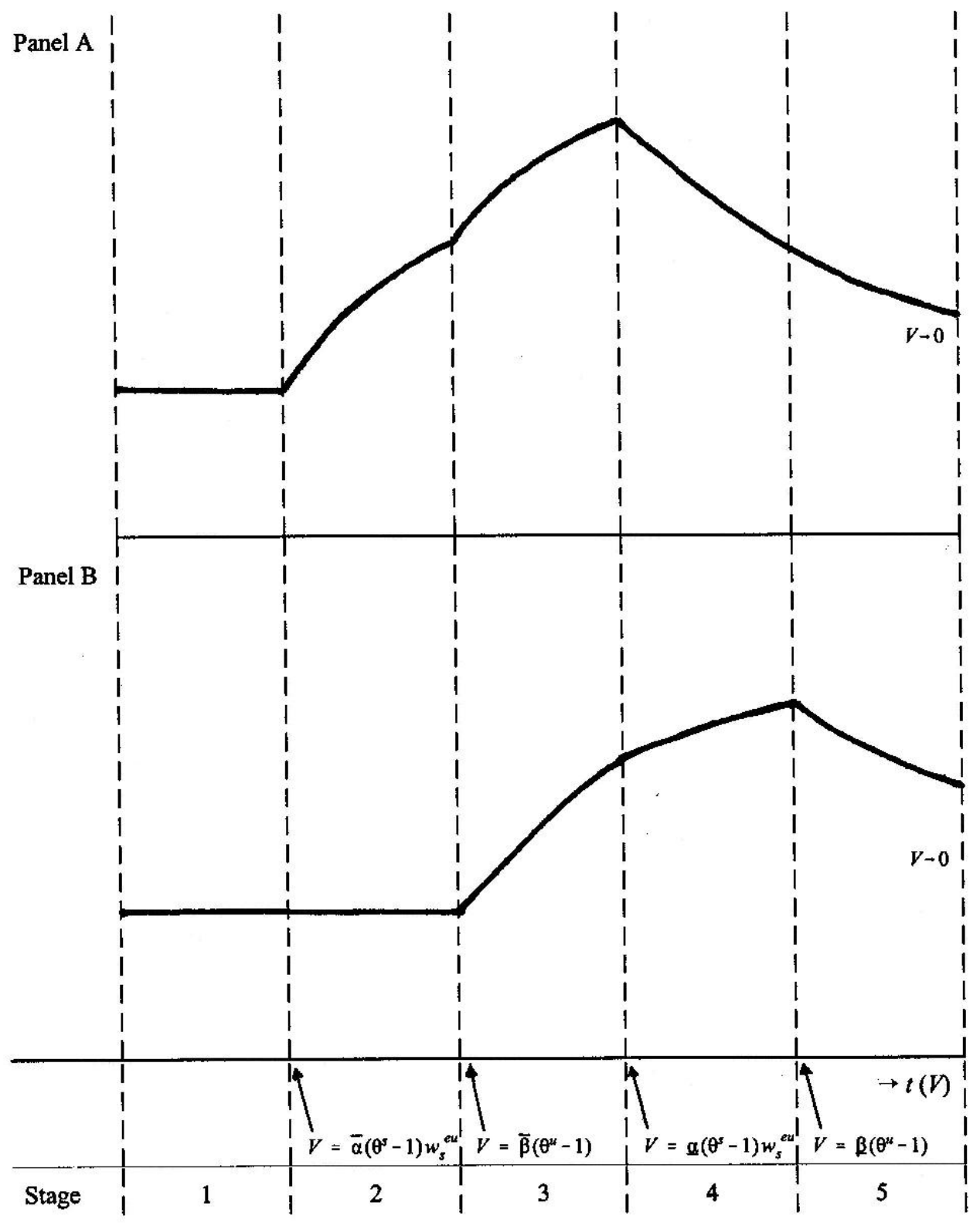


Figure 4

Between-Group Wage Inequality over Time

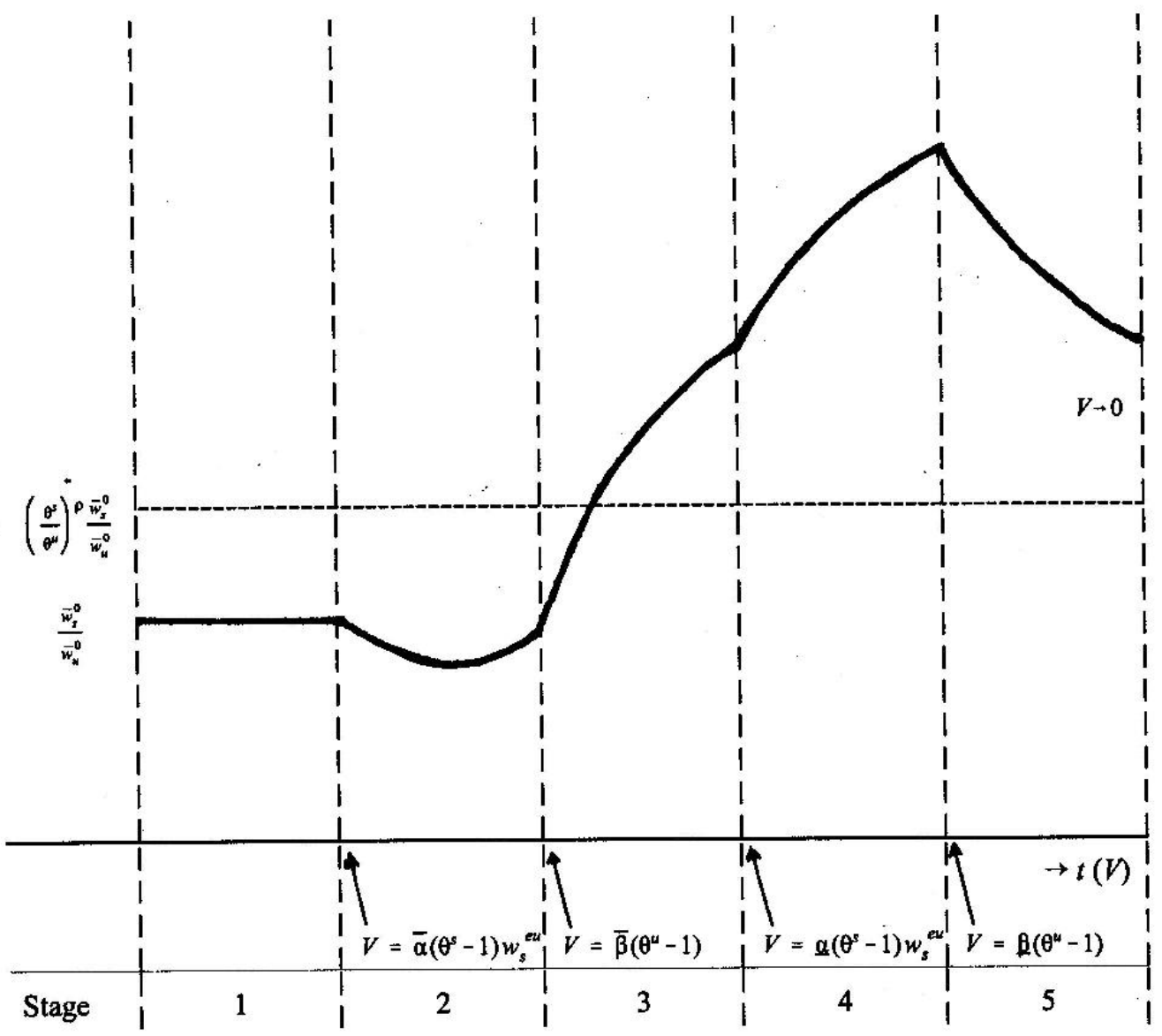




\section{Figure 5}

Imputed Shares of Skilled and Unskilled Workers Using Computers in the United States

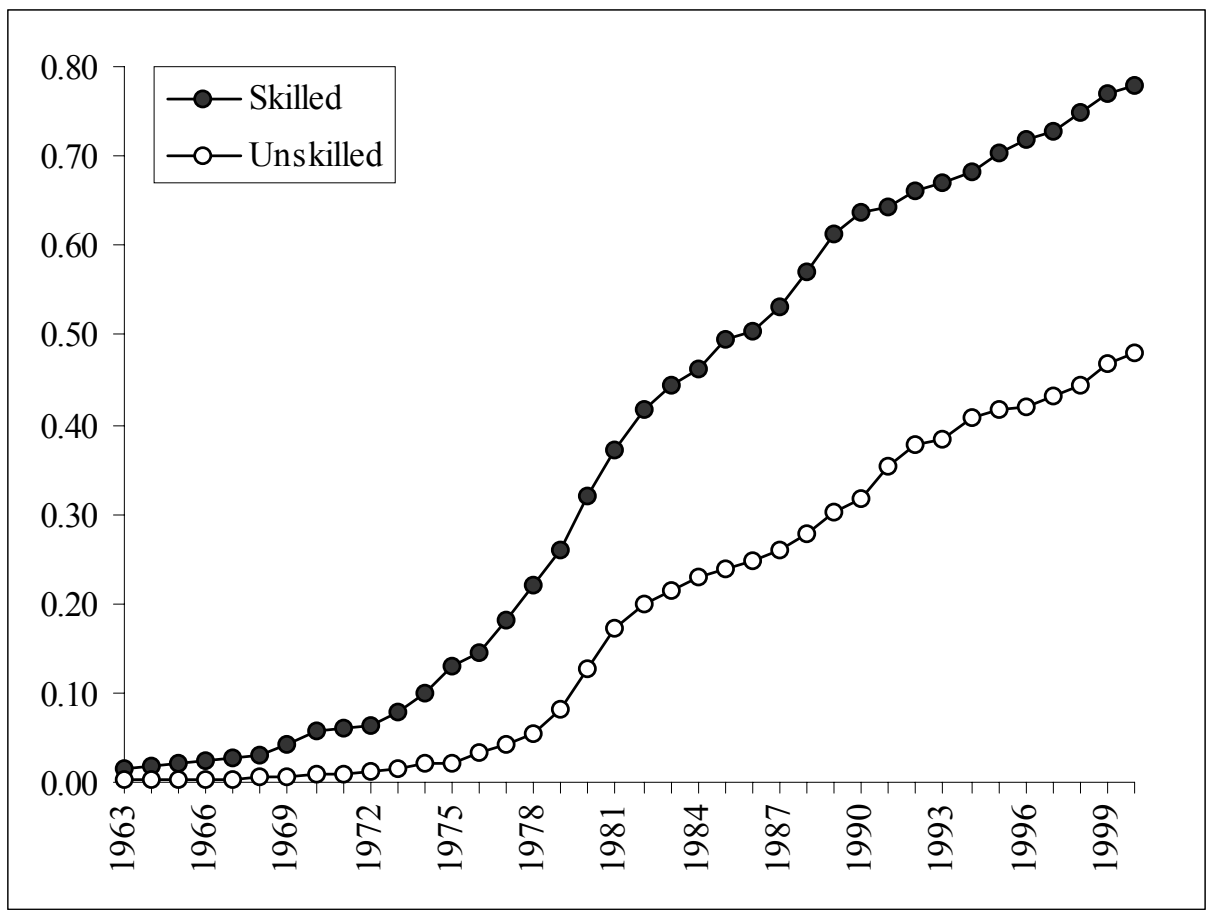

Note: All data are taken from the October and March CPS from 1964 to 2001. The imputed series for computer use are estimated using the October series on computer use and real wages to estimate a wage equation for the years in which computer use is available. This equation is used to impute computer use in the March series from 1964 to 2001. See the Appendix (A.4 and A.5) for more details. 
Figure A.1

Share of Skilled Workers in Total Labor Supply

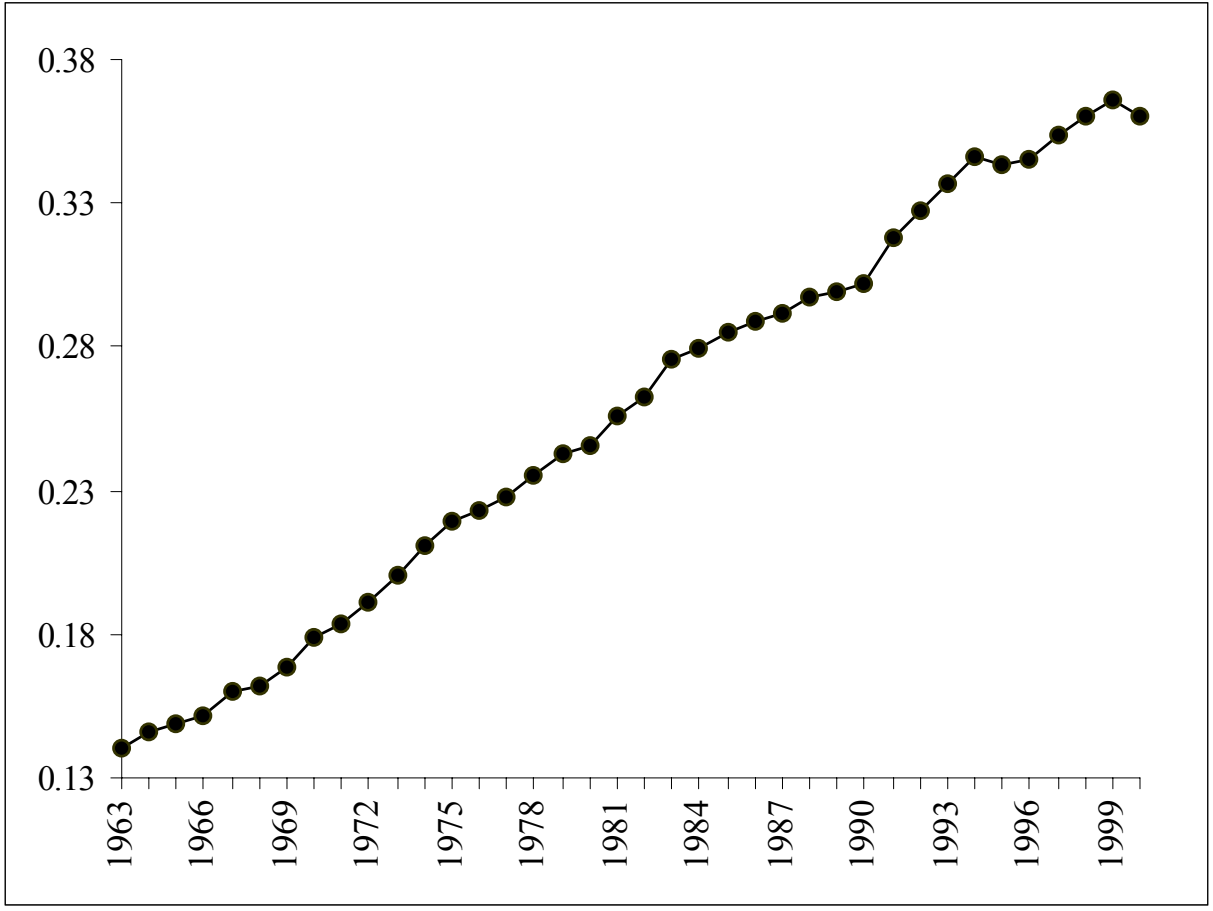

Note: Data are taken from the March CPS. Skilled workers are college graduates and higher; unskilled workers are the remaining ones. See the Appendix (A.1) for further details about the data. 
Table 1

Relative Wages in Efficiency Units in Each of the Five Stages

\section{Stage}

No computer use

The most productive skilled workers use computers

Both types of workers use computers

All skilled and some unskilled workers use computers

All workers use computers

\section{Relative wages in efficiency units}

$$
\frac{w_{s}^{e u}}{w_{u}^{e u}}=\left(\frac{\psi U^{e} p^{u}\left(\bar{\beta}^{\sigma}-\underline{\beta}^{\sigma}\right)}{\chi S^{e} p^{s}\left(\bar{\alpha}^{\sigma}-\underline{\alpha}^{\sigma}\right)}\right)^{1 / \sigma}
$$

$$
\frac{w_{s}^{e u}}{w_{u}^{e u}}=\left(\frac{\psi U^{e} p^{u}\left(\bar{\beta}^{\sigma}-\underline{\beta}^{\sigma}\right)}{\chi S^{e} p^{s}\left(\theta^{s} \bar{\alpha}^{\sigma}-\underline{\alpha}^{\sigma}\right)}+\frac{\left(\theta^{s}-1\right)^{1-\sigma} V^{\sigma}}{\theta^{s} \bar{\alpha}^{\sigma}-\underline{\alpha}^{\sigma}}\right)^{1 / \sigma}
$$

$$
\frac{w_{s}^{e u}}{w_{u}^{e u}}=\left(\frac{\psi U^{e} p^{u}\left(\theta^{u} \bar{\beta}^{\sigma}-\underline{\beta}^{\sigma}\right)+\left(\chi S^{e} p^{s}\left(\theta^{s}-1\right)^{1-\sigma}-\psi U^{e} p^{u}\left(\theta^{u}-1\right)^{1-\sigma}\right) V^{\sigma}}{\chi S^{e} p^{s}\left(\theta^{s} \bar{\alpha}^{\sigma}-\underline{\alpha}^{\sigma}\right)}\right)^{1 / \sigma}
$$

$$
\frac{w_{s}^{e u}}{w_{u}^{e u}}=\left(\frac{\psi U^{e} p^{u}\left(\left(\theta^{u} \bar{\beta}^{\sigma}-\underline{\beta}^{\sigma}\right)-\left(\theta^{u}-1\right)^{1-\sigma} V^{\sigma}\right)}{\chi S^{e} p^{s} \theta^{s}\left(\bar{\alpha}^{\sigma}-\underline{\alpha}^{\sigma}\right)}\right)^{1 / \sigma}
$$

$$
\frac{w_{s}^{e u}}{w_{u}^{e u}}=\left(\frac{\psi U^{e} p^{u} \theta^{u}\left(\bar{\beta}^{\sigma}-\underline{\beta}^{\sigma}\right)}{\chi S^{e} p^{s} \theta^{s}\left(\bar{\alpha}^{\sigma}-\underline{\alpha}^{\sigma}\right)}\right)^{1 / \sigma}
$$


Table 2

Individual Workers' Wages at Different Stages of Computer Diffusion Relative to Worker $j$ with Productivity $\underline{\beta}$

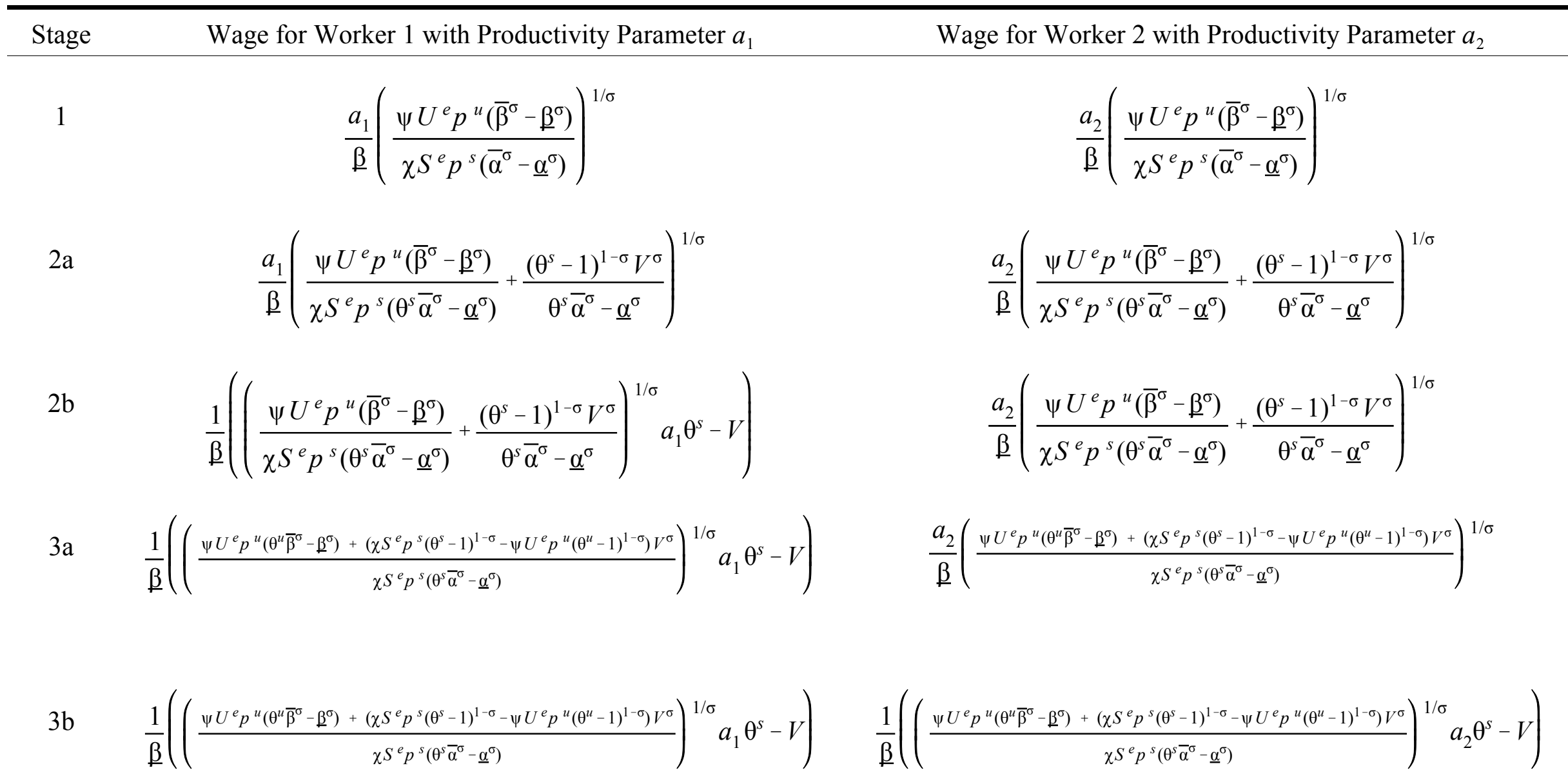




$$
\frac{1}{\left(\underline{\beta} \theta^{u}-V\right)}\left(\left(\frac{\psi U^{e} p^{u} \theta^{u}\left(\bar{\beta}^{\sigma}-\underline{\beta}^{\sigma}\right)}{\chi S^{e} p^{s} \theta^{s}\left(\bar{\alpha}^{\sigma}-\underline{\alpha}^{\sigma}\right)}\right)^{1 / \sigma} a_{1} \theta^{s}-V\right)
$$

$$
\frac{1}{\left(\underline{\beta} \theta^{u}-V\right)}\left(\left(\frac{\psi U^{e} p^{u} \theta^{u}\left(\bar{\beta}^{\sigma}-\underline{\beta}^{\sigma}\right)}{\chi S^{e} p^{s} \theta^{s}\left(\bar{\alpha}^{\sigma}-\underline{\alpha}^{\sigma}\right)}\right)^{1 / \sigma} a_{2} \theta^{s}-V\right)
$$

$$
\frac{a_{1}}{\underline{\beta}} \frac{\theta^{s}}{\theta^{u}}\left(\frac{\psi U^{e} p^{u} \theta^{u}\left(\bar{\beta}^{\sigma}-\underline{\underline{\beta}}^{\sigma}\right)}{\chi S^{e} p^{s} \theta^{s}\left(\bar{\alpha}^{\sigma}-\underline{\alpha}^{\sigma}\right)}\right)^{1 / \sigma}
$$

$$
\frac{a_{2}}{\underline{\beta}} \frac{\theta^{s}}{\theta^{u}}\left(\frac{\psi U^{e} p^{u} \theta^{u}\left(\bar{\beta}^{\sigma}-\underline{\underline{\beta}}^{\sigma}\right)}{\chi S^{e} p^{s} \theta^{s}\left(\bar{\alpha}^{\sigma}-\underline{\alpha}^{\sigma}\right)}\right)^{1 / \sigma}
$$

Note: Computer adoption is assumed to occur in the following order: $\bar{\alpha}, a_{1}, \bar{\beta}, \underline{\alpha}, \underline{\beta}$ and $\bar{\alpha}, \bar{\beta}, a_{2}, \underline{\alpha}, \underline{\beta}$. Stage 1: No computer use; Stage 2a: The most productive skilled worker adopts a computer; Stage 2b: Worker 1 adopts a computer; Stage 3a: The most productive unskilled worker adopts a computer; Stage 3b: Worker 2 adopts a computer; Stage 4: All skilled workers have adopted a computer; and Stage 5: All workers have adopted computers (but the costs of using a computer $V$ might still be positive). Stage 6: $V=0$. 
Table 3

Estimates for Between-Group Wage Inequality

\begin{tabular}{|c|c|c|c|c|c|c|c|c|c|c|c|c|}
\hline & \multicolumn{4}{|c|}{$\begin{array}{l}\text { No Proportional Productivity Gains and } \\
\text { Supply Effects }\end{array}$} & \multicolumn{4}{|c|}{ Equal Proportional Productivity Gains } & \multicolumn{4}{|c|}{ Different Proportional Productivity Gains } \\
\hline & \multirow[b]{2}{*}{ Estimate } & \multirow[b]{2}{*}{$\begin{array}{l}\text { Standard } \\
\text { Error }\end{array}$} & \multicolumn{2}{|c|}{$\begin{array}{l}95 \% \text { confidence } \\
\text { Interval }\end{array}$} & \multirow[b]{2}{*}{ Estimate } & \multicolumn{3}{|c|}{$\begin{array}{l}95 \% \text { confidence } \\
\text { Interval }\end{array}$} & \multirow[b]{2}{*}{ Estimate } & \multirow[b]{2}{*}{$\begin{array}{l}\text { Standard } \\
\text { Error }\end{array}$} & \multicolumn{2}{|c|}{$\begin{array}{l}95 \% \text { confidence } \\
\text { interval }\end{array}$} \\
\hline & & & Lower & Upper & & $\begin{array}{l}\text { Standard } \\
\text { Error }\end{array}$ & Lower & Upper & & & Lower & Upper \\
\hline$\theta$ & & & & & 1.150 & .045 & 1.058 & 1.242 & & & & \\
\hline$\theta^{s}$ & & & & & & & & & 1.272 & .071 & 1.128 & 1.416 \\
\hline$\theta^{u}$ & & & & & & & & & 1.079 & .058 & .961 & 1.197 \\
\hline$\sigma$ & 1.821 & .105 & 1.312 & 2.976 & 2.517 & .556 & 1.388 & 3.646 & 4.298 & 1.837 & .560 & 8.037 \\
\hline$\gamma_{1}$ & .024 & .004 & .015 & .032 & .014 & .004 & .005 & .022 & .009 & .004 & .001 & .017 \\
\hline$\gamma_{0}$ & & & & & .299 & .127 & .042 & .557 & .585 & .264 & .048 & 1.121 \\
\hline $\mathrm{R}^{2}$ & & & & .893 & & & & .885 & & & & .912 \\
\hline
\end{tabular}

Note: All data are taken from the 1964-2001 March CPS files. The dependent variable is the log of the ratio of the average wages of skilled and unskilled workers. Computer use is imputed using the October Supplements to the 1984, 1989, 1993 and 1997 CPS files. See the Appendix for further details about the data. The regressions are performed by non-linear least squares. See the Econometric Specification in the Appendix (A.6) for further details. 
Table 4

Estimates for Within-Group Wage Inequality

\begin{tabular}{|c|c|c|c|c|c|c|c|c|}
\hline & \multicolumn{4}{|c|}{ Skilled workers } & \multicolumn{4}{|c|}{ Unskilled workers } \\
\hline & \multicolumn{6}{|c|}{$\begin{array}{c}95 \% \text { confidence } \\
\text { interval }\end{array}$} & \multicolumn{2}{|c|}{$\begin{array}{c}95 \% \text { confidence } \\
\text { interval }\end{array}$} \\
\hline & Estimate & $\begin{array}{l}\text { Standard } \\
\text { Error }\end{array}$ & Lower & Upper & Estimate & $\begin{array}{c}\text { Standard } \\
\text { Error }\end{array}$ & Lower & Upper \\
\hline$\theta^{s}$ & 1.413 & .029 & 1.354 & 1.472 & & & & \\
\hline$\theta^{u}$ & & & & & 1.412 & .047 & 1.317 & 1.507 \\
\hline$\gamma_{0}$ & 3.524 & .030 & 3.463 & 3.584 & 3.634 & .033 & 3.568 & 3.700 \\
\hline $\mathrm{R}^{2}$ & & & & .883 & & & & .751 \\
\hline
\end{tabular}

Note: All data are taken from the 1964-2001 March CPS files. The dependent variable is the $\log$ of the $90^{\text {th }}-10^{\text {th }}$ percentile wage differential within both groups. Computer use is imputed using the October Supplements to the 1984, 1989, 1993 and 1997 CPS files. See the Appendix for further details about the data. The regressions are performed by non-linear least squares. See the Econometric Specification in the Appendix (A.6) for further details. 